\title{
Connexin32 Is a Myelin-Related Protein in the PNS and CNS
}

\author{
Steven S. Scherer, ${ }^{1}$ Suzanne M. Deschênes, ${ }^{1}$ Yi-tian Xu, ${ }^{1}$ Judith B. Grinspan, ${ }^{2}$ Kenneth H. Fischbeck, ${ }^{1}$ and \\ David L. Paul ${ }^{3}$ \\ ${ }^{1}$ Department of Neurology, University of Pennsylvania, Philadelphia, Pennsylvania 19104-6146, 2 Division of \\ Neurological Research, Children's Hospital of Philadelphia, Philadelphia, Pennsylvania 19104, and 'Department of \\ Neurobiology, Harvard Medical School, Boston, Massachusetts 02115-6092
}

\begin{abstract}
We have examined the expression of a gap junction protein, connexin32 (Cx32), in Schwann cells and oligodendrocytes. In peripheral nerve, $\mathrm{Cx} 32$ is found in the paranodal myelin loops and Schmidt-Lanterman incisures of myelinating Schwann cells, and the levels of Cx32 protein and mRNA change in parallel with those of other myelin-related genes during development, Wallerian degeneration, and axonal regeneration. In the central nervous system, $\mathrm{C} \times 32$ is found in oligodendrocytes and their processes, but not in compact myelin, and the levels of Cx32 protein and mRNA increase during development in parallel with those of the other myelin genes. Thus, Cx32 is expressed as part of the myelinating phenotype of both Schwann cells and oligodendrocytes, indicating that this gap junction protein plays in important role in the biology of myelin-forming cells.
\end{abstract}

[Key words: Cx32, gap junctions, Schwann cells, oligodendrocytes, myelin, incisures]

Myelin is the multi-lamellar structure that surrounds axons and increases axonal conduction velocity. It is formed by the spiral wrapping of the cell membrane of myelinating glia-oligodendrocytes in the CNS and Schwann cells in the PNS. The myelin sheaths produced by these two cell types are structurally similar, consisting mostly of compact myelin that is characterized by a unique but overlapping set of proteins (Lemke, 1992, 1993). Protcolipid protcin (PLP) and myclin basic protein (MBP) are the major structural proteins in the CNS, while protein zero $\left(\mathrm{P}_{0}\right)$, $\mathrm{MBP}$, and peripheral myelin protein-22 kD (PMP-22) are the major proteins in the PNS. Each of these myelin proteins is essential for proper myelination, as mutations in PLP and MBP cause dysmyelination in the CNS, and mutations in $\mathrm{P}_{0}$ and PMP22 cause dysmyelination in the PNS (Hudson, 1990; Chance and Pleasure, 1993; Lemke, 1993; Snipes and Suter, 1995).

The compact myelin in the PNS contains periodic interruptions called Schmidt-Lanterman incisures or clefts (Peters et al., 1991). These incisures, as well as the paranodal regions of the

\footnotetext{
Received June 22, 1995; revised Aug. 17, 1995; accepted Aug. 24, 1995.

We thank Shelly Whyatt and Susan Shumas for technical assistance, and Drs. David Colman, Rory Curtis, Susan Hockfield, John Kamholz, Arnulf Koeppen, Sara Piddlesden, James Salzer, and David Schreyer for their generous gifts of antibodies. This work was supported by grants from the Muscular Dystrophy Association, 'The American Academy of Neurology (Murray M. Stokely Award), and the NIH (NS08075 and NS01565).

Correspondence should be addressed to Steven S. Scherer, Department of Neurology, Clinical Research Building, University of Pennsylvania, Pliladelphia, PA 19104-6146.

Copyright 1995 Society for Neuroscience $0270-6474 / 95 / 158281-14 \$ 05.00 / 0$
}

myelin sheath, contain a distinct group of proteins, including myclin-associated glycoprotein $(\mathrm{M} \Lambda \mathrm{G})$, connexin32 (Cx32), E-cadherin, and oligodendrocyte-myelin glycoprotein (Trapp et al., 1989; Bergoffen et al., 1993; Apostolski et al., 1994; Fannon et al., 1995). Incisures have also been reported in the CNS (Peters et al., 1991), but no molecules have yet been found to be preferentially localized to CNS incisures. The importance of the incisures to the normal function of myelinated axons was not appreciated until it was found that the $\mathrm{X}$-linked form of CharcotMarie-Tooth disease (CMTX) was caused by mutations in the Cx32 gene (Bergoffen et al., 1993). Cx32 is a gap junction protein and is expressed in many tissues, including oligodendrocytes and myelinating Schwann cells (Kumar and Gilula, 1986; Paul, 1986; Dermietzel et al., 1989, 1990; Bennett et al., 1991; Kumar and Gilula, 1992; Bergoffen et al., 1993). How Cx32 mutations cause peripheral neuropathy is unknown. One plausible explanation is that CMTX mutations alter the function of gap junctions at nodes and incisures, as Cx32-immunoreactivity colocalizes with gap junctions seen by freeze-fracture electron microscopy (Sandri et al., 1982; Bergoffen et al., 1993), and some mutations in $\mathrm{Cx} 32$ disrupt the formation of functional gap junctions (Bruzzone et al., 1994; Rabadan-Diehl et al., 1994). If CMTX mutations disrupted these gap junctions, this could interrupt the diffusion of ions and small molecules in a radial direction, directly across the myelin sheath, through the paranodes and incisures.

To learn more about the role of $\mathrm{Cx} 32$ in myelinating glia, we examined the localization and expression of Cx32 in Schwann cells and oligodendrocytes. In the PNS, Cx32 is found in the paranodal regions and incisures of myelinating Schwann cells. In the CNS, Cx32 is found in cell bodies and processes of oligodendrocytes, but not in compact myelin or Schinidt-Lanterman incisures. Axon-Schwann cell interactions in vivo, and cAMP analogs in vitro, increase Cx32 expression in Schwann cells. In the CNS, the level of Cx32 mRNA increases in different regions in parallel with those of the other myelin genes. Furthermore, in jimpy mice and myelin-deficient rats, which have PLP mutations that result in the failure of oligodendrocyte maturation (Hudson, 1990), the level of Cx32 mRNA, like those of other myelin-related genes, does not increase during the period of myelination. Thus, $\mathrm{Cx} 32$ is expressed as part of the program of myelin gene expression in both oligodendrocytes and Schwann cells, but is localized to different parts of each cell.

\section{Materials and Methods}

Surgery and collection of tissues. Using aseptic technique, the sciatic nerves of anesthetized $(50 \mathrm{mg} / \mathrm{kg}$ pentobarbital i.p.), adult (10-13 week 
old) Sprague-Dawley rats were exposed at the sciatic notch. Permanent axotomy was accomplished by doubly ligating nerves, transecting between the ligatures with iridectomy scissors, and suturing the two nervestumps were at least $1 \mathrm{~cm}$ apart; this technique prevents axonal regeneration to the distal nerve-stump for at least 2 months. Nerve-crush was produced by tightly compressing the sciatic nerve at the sciatic notch with flattened forceps twice, each time for $10 \mathrm{sec}$; this technique causes all of the axons to degenerate, but allows axonal regeneration. At various times after nerve-injury, the animals were sacrificed by $\mathrm{CO}_{2}$ inhalation, the distal nerve-stumps were removed, and the most proximal 2-3 $\mathrm{mm}$ were trimmed off. For transected nerves, the entire distal nerve-stump was taken from just below the lesion to the ankle (about $4 \mathrm{~cm}$ ). For crushed nerves, the distal nerve-stump was divided into two equal segments, termed the proximal and distal segments, each about 2 cin long. The nerves were immediately frozen in liquid nitrogen and stored at $-80^{\circ} \mathrm{C}$. Unlesioned sciatic nerves and various brain regions were obtained from animals of different ages, from P1 (the day after birth) to P90. All animal protocols were approved by the Institutional Animal Care and Use Committee of The University of Pennsylvania.

Cell culture. Schwann cells were isolated from $3 \mathrm{~d}$ old rat pups (Brockes et al., 1979), and expanded on $10 \mathrm{~cm}$ plates coated with polyL-lysine in DME supplemented with $10 \%$ FCS, a crude extract of glial growth factor (Brockes et al., 1980), and $2 \mu \mathrm{M}$ forskolin (Porter et al., 1986). The cells were passaged three times, grown to confluence, then switched for $3 \mathrm{~d}$ to either DMEM $+10 \%$ FCS, or DMEM $+10 \%$ FCS supplemented with $4 \mu \mathrm{M}$ forskolin. All of the cultures used in these experiments were $>95 \%$ Schwann cells, as judged by staining for the low-affinity nerve growth factor receptor (NGFR; data not shown). Fibroblasts were obtained by culturing the perineurium in DMEM $+10 \%$ FCS on uncoated plastic plates, to which Schwann cells did not adhere. RNA and protein were isolated after the cells had been passaged three times.

Immunohistochemistry and immunocytochemistry. Nerve fibers were teased from fresh, unfixed nerves, or from nerves that had been fixed for $30 \mathrm{~min}$ in $4 \%$ paraformaldehyde or Zamboni's fixative. Teased fibers were dried on glass slides, then postfixed for $10 \mathrm{~min}$ with acetone. The best Cx32 labeling was obtained from tissucs that were cmbedded in OCT (Miles, Elkhart, IN), without prior fixation or after fixation in $4 \%$ paraformaldehyde. Frozen sections of unfixed tissue were postfixed for $10 \mathrm{~min}$ in acetone. Teased fibers and sections were blocked for at least $1 \mathrm{hr}$ in $10 \%$ fish skin gelatin containing $0.5 \%$ Triton $\mathrm{X}$, and incubated $24-48 \mathrm{hr}$ at $4^{\circ} \mathrm{C}$ with various combinations of primary antibodies. We used mouse monoclonal antibodies against rat $\mathrm{Cx} 32$ (M12.13, (Goodenough et al., 1988), $P_{o}$ (Archelos et al., 1993), MAG (BoehringerMannheim, Indianapolis, IN). myelin-oligodendrocyte glycoprotein (MOG; Linnington et al., 1984), growth-associated protein-43 kD (GAP-43; Schreyer and Skene, 1991), and rabbit polyclonal antibodies against rat $\mathrm{C} \times 32$ (Goodenough et al., 1988), MAG (Pedraza et al., 1990), PLP (Koeppen et al., 1988), $P_{0}$ (D'Urso et al., 1990), nestin (Friedman et al., 1990), GAP-43 (Curtis et al., 1992), and ED1 (Serotec; England). After incubating with the primary antibodies, the sections were washed, then incubated with the appropriate fluorescein-, rhodamine-, or biotin-conjugated donkey anti-rabbit and anti-mouse secondary antibodies (Jackson ImmunoResearch Laboratories, West Grove, PA). Fluorescein- or rhodamine-conjugated avidin was used to visualize biotin-conjugated antibodies.

The rabbit antiserum against $\mathrm{Cx} 32$ was an unfractionated serum generated against a synthetic peptide corresponding to amino acids 98-124 of Cx.32 (Paul, 1986; Goodenough et al., 1988). This antibody recognizes $\mathrm{Cx} 32$ on Western blots and labels gap junctions by immunoelectron microscopy (Paul, 1986; Goodenough et al., 1988). Preincubation of the antiserum with the peptide against which it was raised abolishes Cx32 staining in several tissues (D. Paul, unpublished observations). The monoclonal antibody against rat $\mathrm{Cx} 32$ (M12.13) probably recognizes an epitope in the C-terminal cytoplasmic domain (Goodenough et al., 1988). In peripheral nerve and spinal cord both the polyclonal and the monoclonal antibodies gave identical patterns of staining. Furthermore, the preimmune rabbit serum, diluted to have the same protein concentration as the antiserum itself, did not label either peripheral nerve or spinal cord.

Western blotting. Protein homogenates were obtained by pulverizing frozen tissues with a steel mortar and pestle on dry ice, homogenized in $50 \mathrm{mM}$ Tris (pH 7.0) containing 1\% SDS and $100 \mu \mathrm{M}$ PMSF, then sonicated. Protein extracts were similarly prepared from cultured Schwann cells after scraping the cells into the same solution. A myelin preparation was isolated from cerebrum, brainstem, and spinal cord of adult rats (Norton and Poduslo, 1973), lyophilized, and resuspended in the same solution. Insoluble material was removed by centrifugation in a microfuge for $15 \mathrm{~min}$ at $15,000 \mathrm{rpm}$, and the concentration of protein in the supernatant was measured with a Bio-Rad DC Assay kit according to the manufacturer's instructions. Equal amounts $(25 \mu \mathrm{g})$ of protein were separated on $12 \%$ acrylamide, $0.1 \%$ SDS gels, transferred to Immobilon PVDF membrane (NEN Research Systems, Boston, MA), blocked $5 \%$ powdered milk in TRIS-buffered saline containing $0.5 \%$ Tween 20) overnight at $4^{\circ} \mathrm{C}$, then incubated with a rabbit antiserum against rat Cx32 (Goodenough et al., 1988), diluted 1:5000, for $24 \mathrm{hr}$ at $4^{\circ} \mathrm{C}$. The membranes were washed in blocking solution, then incubated at room temperature in peroxidase-coupled donkey anti-rabbit immunoglobulin (Jackson ImmunoResearch Laboratory, West Grove, PA), diluted 1:10,000. After $1 \mathrm{hr}$, the membranes were washed, developed with chemiluminescence reagent (ECL kit, Amersham, Arlington Heights, IL), and exposed to film (Kodak X-OMAT AR imaging film). The membranes were reprobed with a rabbit antiserum against a peptide encoded by exon 1 of human MBP (diluted 1:5000; DeFerra et al., 1985), a rabbit antiserum against $P_{0}$ (diluted 1:5000; D'Urso et al., 1990), or a rabbit antiserum against PLP (diluted 1:2000; Koeppen et al., 1988). To show the specificity of the primary antibodies, duplicate membranes were similarly prepared, but the primary antihody was omitted.

Northern blotting. RNA was isolated from rat sciatic nerves and Schwann cells by $\mathrm{CsCl}_{2}$ gradient centrifugation (Chirgwin et al., 1979). Equal amounts $(10 \mu \mathrm{g})$ of total RNA were electrophoresed in $1 \%$ agarose, $2.2 \mathrm{M}$ formaldehyde gels, transferred to nylon membranes (Duralon, Stratagene) in $6 \times \mathrm{SSC}$, and u.v. cross-linked (0.12 joules). Blots were prehybridized, hybridized, and washed using standard techniques; the final stringency of the wash was $0.2 \times \mathrm{SSC}$ at $65^{\circ} \mathrm{C}$ for $30 \mathrm{~min}$ (Sambrook et al., 1989). The following cDNAs were used as probesa $1.1 \mathrm{~kb}$ fragment of rat Cx32 (Paul, 1986), a full-length cDNA of rat $P_{0}$ (Lemke and Axel, 1985), a $0.7 \mathrm{~kb}$ Bam HI fragment of rat NGFR (Radeke et al., 1987), and a full-length cDNA of rat glyceraldehyde 3-phosphate dehydrogenase (GAPDH; (Fort et al., 1985). Plasmid inserts were isolated after restriction endonuclease digestion by agarose gel electrophoresis, and purified by electroelution. ${ }^{32} \mathrm{P}$-Labeled cDNA probes with specific activities of $2-5 \times 10^{9} \mathrm{cpm} / \mu \mathrm{g}$ were prepared by primer extension with random hexamers using the Prim-a gene kit (Pro mega) according to the manufacturer's instructions.

\section{Results}

\section{Cx32 is expressed by myelinating Schwann cells}

In our initial report, we found that $\mathrm{C} \times 32$ appeared to be localized to the paranodes and Schmidt-Lanterman incisures of PNS myelin (Bergoffen et al., 1993). We have confirmed and extended this observation by double-labeling cryosections and teased fibers for $\mathrm{Cx} 32$ and MAG, pairing a mousc monoclonal antibody against Cx32 with a rabbit polyclonal antibody against MAG, and a rabbit polyclonal antibody against $\mathrm{Cx} 32$ with a mouse monoclonal antibody against MAG. Both combinations of antibodies gave similar results. In agreement with previous reports (Sternberger et al., 1979; Trapp and Quarles, 1982, 1984; Trapp et al., 1984), Figure $1 B$ demonstrates that MAG-immunoreactivity was found around the entire adaxonal surface of myelinating Schwann cells (arrowheads), which apposes the axon, and in the incisures (arrows) and paranodes (not shown). Figure $1 \mathrm{~A}$ demonstrates that Cx32-immunoreactivity colocalized with MAG at the incisures. At the adaxonal Schwann cell membrane, however, there was only a thin line of $\mathrm{C} \times 32$ staining, which probably corresponded to the inner mesaxon (Peters et al., 1991). We also performed double-labeling for $\mathrm{Cx} 32$ and $\mathrm{P}_{0}$ (Fig. 2). $\mathrm{P}_{0}$ was found throughout the compact myelin (Fig. 2B; Trapp et al., 1981), whereas Cx32 staining (Fig. 2A) was chiefly found at incisures (arrows) and paranodes (arrowheads). Thus, the localization of $\mathrm{Cx} 32$ in mature myelinated axons matches the localization of gap junctions in the PNS myelin sheath by freezefracture - at the paranodes, incisures, and inner mesaxon (Sandri 


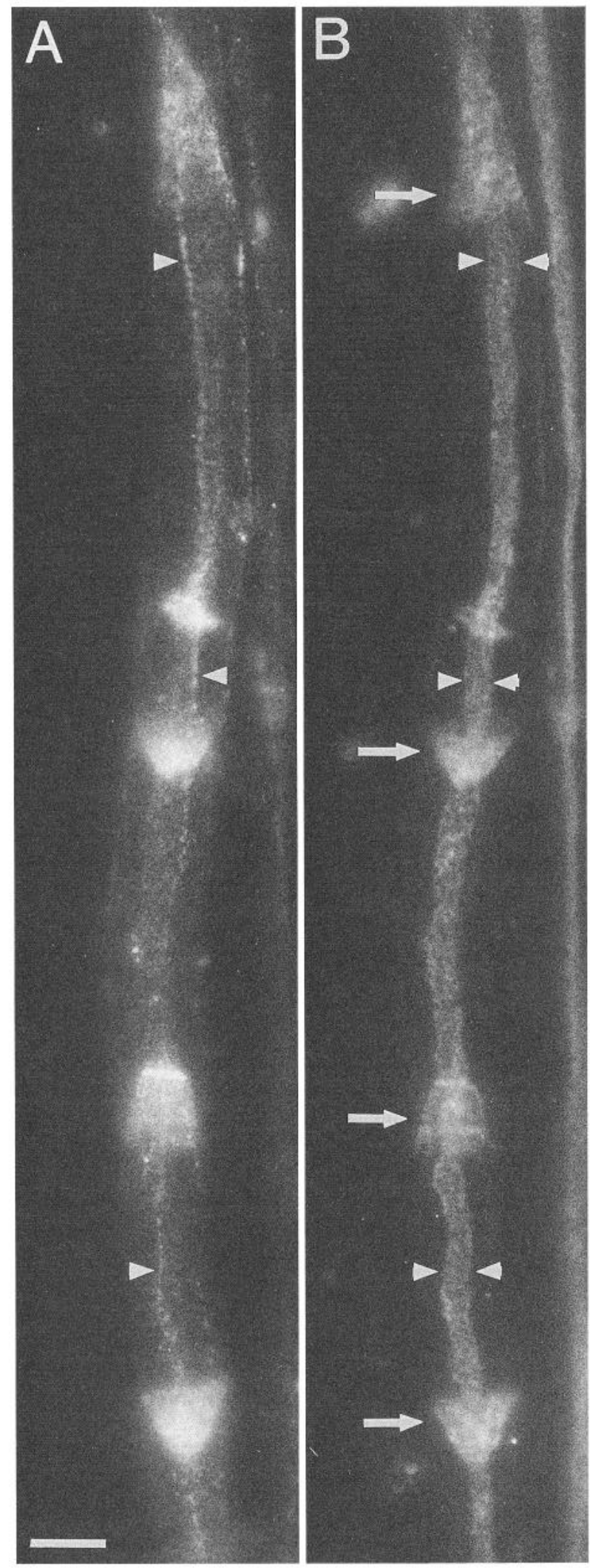

Figure 1. Immunohistochemical analysis of Cx32 and MAG in adult sciatic nerve. These are photomicrographs of a teased fiber that was labelled with a combination of a mouse monoclonal antibody against rat $\mathrm{Cx} 32(A)$ and a rabbit antiserum against MAG $(B)$ and visualized with fluorescein- and rhodamine-coupled secondary antibodies, respectively. Cx32- and MAG-immunoreactivity colocalize at incisures (arrows), which are conical structures that traverse the unstained compact et al., 1982). In addition, we also noted perinuclear Cx32 staining (data not shown), as has been noted for other components of the myelin sheath (Trapp et al., 1981).

To determine whether $\mathrm{Cx} 32$ is expressed in nonmyelinating Schwann cells, we examined teased fibers in the cervical sympathetic trunk, which is composed of unmyelinated axons, their associated (nonmyelinating) Schwann cells, as well as a few, thinly myelinated axons (Aguayo et al., 1976). As shown in Figure $3, A$ and $B$, there was an identical pattern of adaxonal Cx32- and MAG-immunoreactivity, respectively, in myelinating Schwann cells (arrows). Thus, Cx32-immunoreactivity was not confined to the inner mesaxon of these small myelinated fibers, but appeared to surround their entire adaxonal circumference. These small myelinated axons had internodal lengths of only 50-70 $\mu \mathrm{m}$, and typically lacked incisures, like the fibers shown in Figure 3. When incisures were present, they were Cx32- and MAG-positive (data not shown). Nonmyelinating Schwann cells also had $\mathrm{Cx} 32$-immunoreactivity, although this staining was punctate and discontinuous, and overall significantly less than that seen in myelinating Schwann cells (Fig. $3 A$ ). We confirmed that these were nonmyelinating Schwann cells by double-labeling for both Cx32 and GAP-43, as GAP-43 labels unmyelinated axons and their associated nonmyelinating Schwann cells (data not shown; see Curtis et al., 1992).

To examine the onset of $\mathrm{Cx} 32$ expression during development, we examined teased fibers and sections of postnatal day 6 (P6) sciatic nerves. At this age, the sciatic nerve contains axons at many stages of ensheathment, including axons that have just begun to be myelinated (Webster and Favilla, 1984). There were many myelin sheaths in P6 nerves, and some had incisures that were MAG-positive, but there was little, if any, detectable Cx32 staining of incisures. The Cx32 staining that was present appeared to be associated with the inner mesaxon (data not shown). Thus, the onset of Cx32 expression in the incisures and paranodes may lag that of MAG.

Axotomy disrupts axon-Schwann cell interactions, causing the degeneration of the axons and their myelin sheaths, and a dramatic reduction in the expression of myelin-related proteins (Mirsky and Jessen, 1990; Scherer and Asbury, 1993). We examined $\mathrm{Cx} 32$ expression in nerves that were transected to cause permanent axotomy, as well as nerves were focally crushed, to cause Wallerian degeneration but promote axonal regeneration. In permanently transected nerves, $\mathrm{Cx} 32$ disappeared from myelinating Schwann cells in parallel with the loss of MAG (data not shown). The Schwann cells themselves, however, persisted, and could be labelled with an antibody against nestin (Fig. 4). At 58 d posttransection, Cx32-, MAG-, $\mathrm{P}_{0^{-}}$, and MBP-immunoreactivity were found macrophages (Stoll et al., 1989), which were ED1-positive and nestin-negative (Fig. 4). In crushed nerves, Cx32-immunoreactivity was found in incisures and paranodal regions of remyelinated fibers by $24 \mathrm{~d}$ postlesion (data not shown). These data demonstrate that the expression of $\mathrm{Cx} 32$ protein is linked to the formation of the myelin sheath in Schwann cells.

To confirm that peripheral nerve contains $\mathrm{Cx} 32$, and to substantiate the changes in $\mathrm{Cx} 32$ protein expression after nerve-

$\leftarrow$

myelin sheath. MAG also surrounds the axon at the adaxonal Schwann cell surface (between arrowheads in B), whereas only a thin line of Cx32 staining is found at the adaxonal surface, probably at the inner mesaxon (arrows in A). Scale bar, $10 \mu \mathrm{m}$. 
8284 Scherer et al. $•$ Connexin32 Is a Myelin-Related Protein

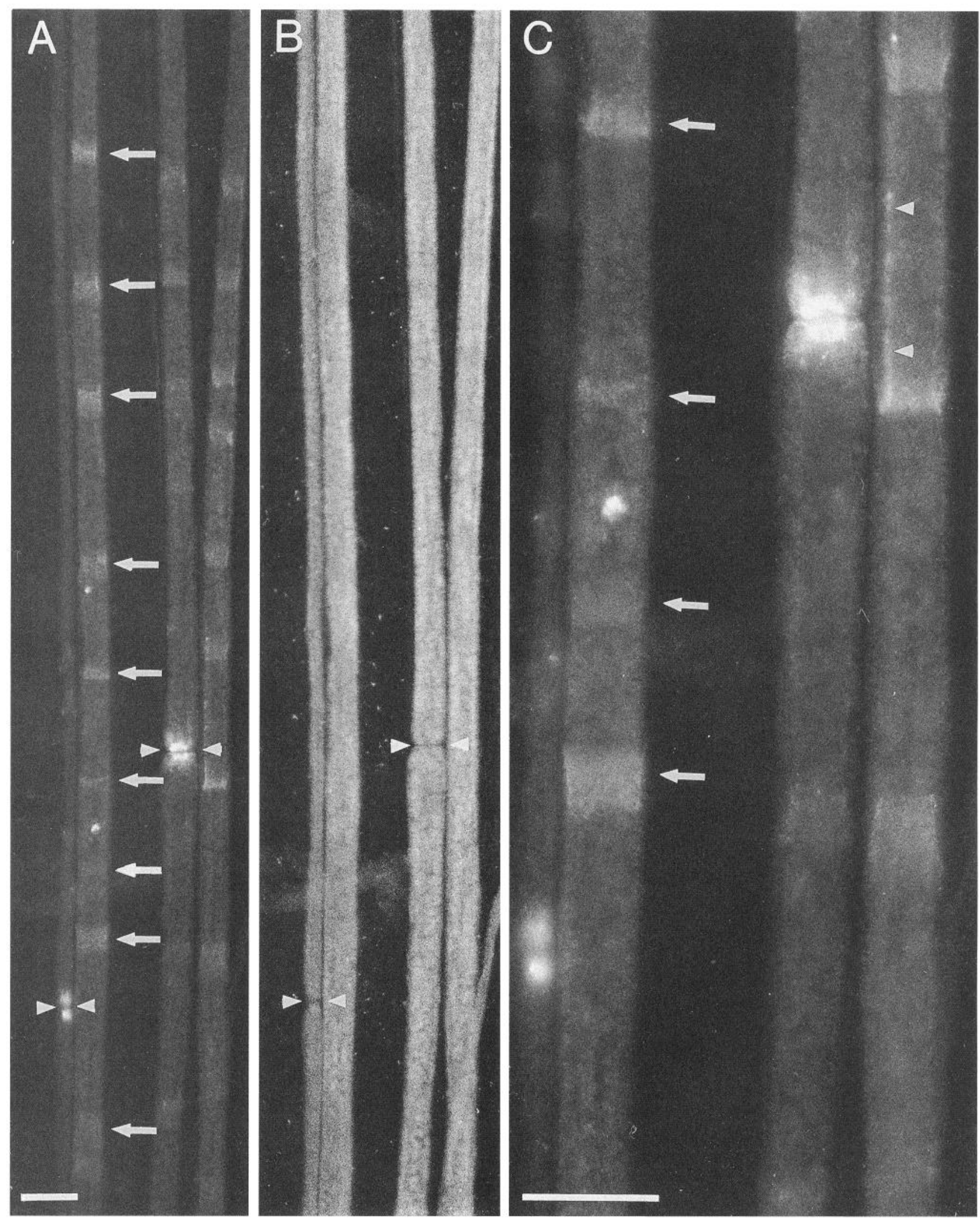

Figure 2. Immunohistochemical localization of $\mathrm{Cx} 32$ and $\mathrm{P}_{0}$ in adult sciatic nerve. These are photomicrographs of teased fibers, double-labeled with a monoclonal antibody against rat $\mathrm{Cx} 32(A, C)$ and a rabbit polyclonal antibody against rat $\mathrm{P}_{0}(B)$ and visualized with fluorescein- and rhodamine-coupled secondary antibodies, respectively. Note that $\mathrm{Cx} 32$ is predominantly found at the incisures (some of which are indicated by arrows in $A$ ) and paranodes (arrowheads in $A$ and $B$ ), whereas the $\mathrm{P}_{0}$ is found throughout the compact myelin sheath. $C$ is an enlargement of the node shown in $A$, and shows Cx32 staining of the inner mesaxon (arrowheads). Scale bars, $10 \mu \mathrm{m}$. 

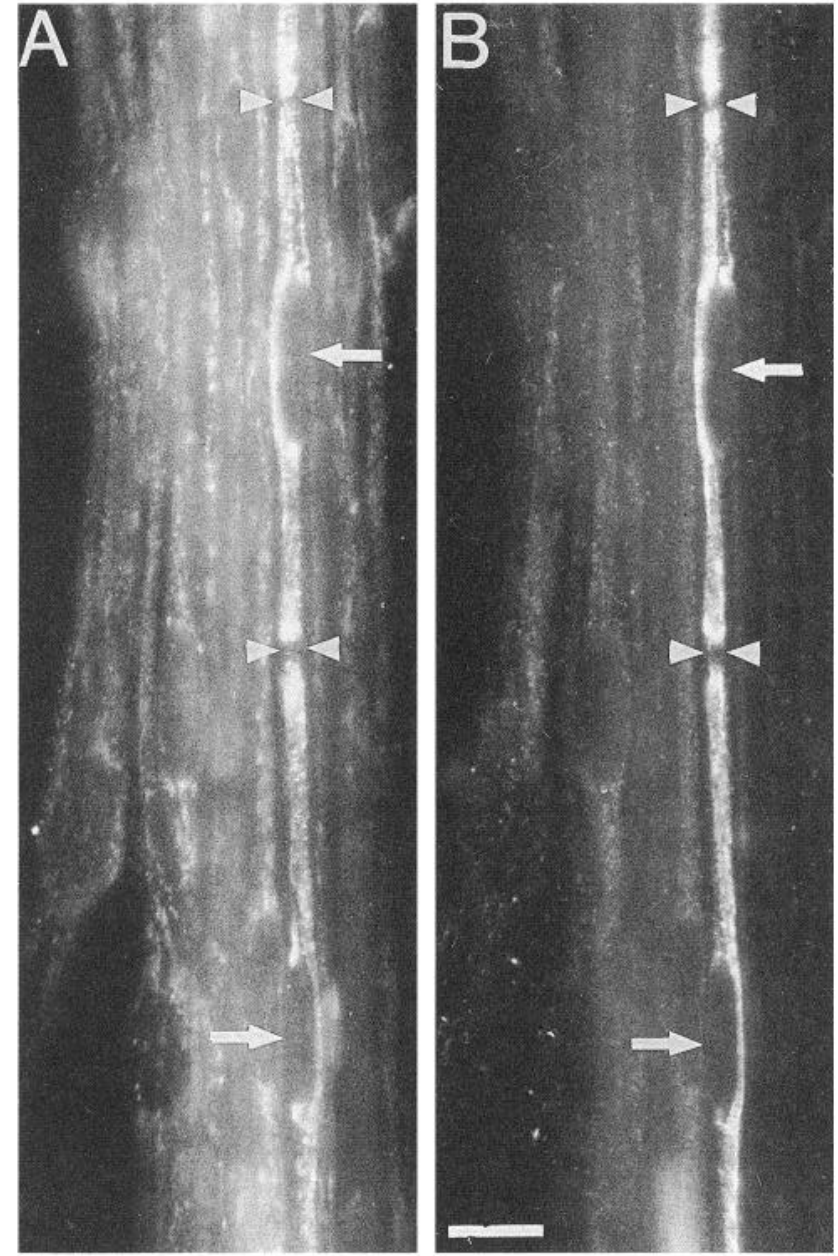

Figure 3. Immunohistochemical localization of $\mathrm{Cx} 32$ and MAG in adult cervical sympathetic trunk. These are photomicrographs of a bundle of teased fibers, double-labeled with a monoclonal antibody against rat $\mathrm{Cx} 32(A)$ and a rabbit polyclonal antibody against rat MAG $(B)$ and visualized with fluorescein- and rhodamine-coupled secondary antibodies, respectively. There is a single myelinated fiber in this field, with two internodes (the arrows indicate the positions of the two Schwann cell nuclei), separated by nodes (arrowheads). The pattern of Cx32 and MAG staining of the two myelinating Schwann cells is essentially identical; neither one appears to have an incisure and the immunoreactivity is not restricted to the paranodes. Note that many nonmyelinating Schwann cells have some Cx32 staining, but little MAG staining. Scale bar, $10 \mu \mathrm{m}$.

injury, we performed Western blot analysis using a rabbit antibody against rat $\mathrm{Cx} 32$. As shown in Figure $5 A$, in unlesioned nerves (the lanes labeled " 0 "), this antibody recognized a protein of approximately $32 \mathrm{kDa}$ molecular mass (arrowhead), as well as a dimer of $\mathrm{Cx} 32$ (double arrowhead), which results from the incomplete solubilization of Cx32 in SDS (Paul, 1986). The amount of $\mathrm{Cx} 32$ fell between 1 and $12 \mathrm{~d}$ posttransection, and did not increase thereafter. Prolonged exposure of the blot, however, demonstrated detectable Cx32 even at $60 \mathrm{~d}$ (data not shown). In crushed nerves, the amount of $\mathrm{Cx} 32$ fell between 1 and $12 \mathrm{~d}$, as in transected nerves, but returned to near normal levels by $60 \mathrm{~d}$ post-crush. Reprobing the blots for $\mathrm{P}_{0}$ demonstrated that the amount of this myelin protein also fell progressively in permanently transected nerves, and returned to normal in crushed nerves at $60 \mathrm{~d}$ (Fig. 5B). These data demonstrate that $\mathrm{Cx} 32$ is found in peripheral nerve, and that the amount of $\mathrm{Cx} 32$
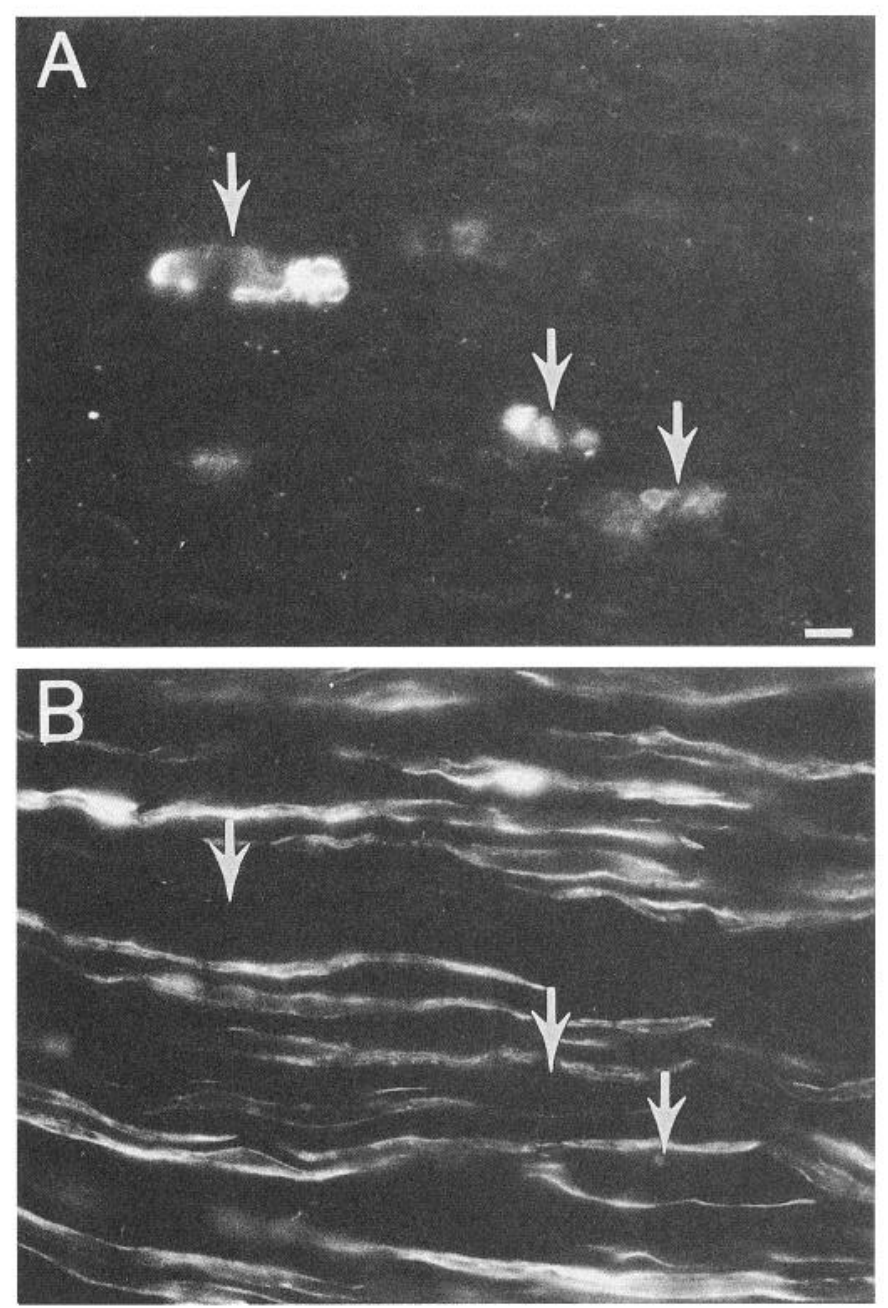

Figure 4. Immunohistochemical localization of $\mathrm{Cx} 32$ in permanently axotomized adult sciatic nerve. These are photomicrographs of the same field of a longitudinal section of nerve $58 \mathrm{~d}$ post transection, doublelabeled for $\mathrm{Cx} 32$ (rhodamine, $A$ ) and (nestin; fluorescein, $B$ ). The arrows indicate three macrophages that have Cx32-immunoreactivity $(A)$ but are nestin-negative $(B)$. The nestin-positive structures are Schwann cell processes. Scale bar, $10 \mu \mathrm{m}$.

protein, like many myelin proteins, depends on the maintenance of axonal interactions (Mirsky and Jessen, 1990; Scherer and Asbury, 1993).

Cx32 mRNA is expressed in concert with other myelin-related genes and is regulated by axon-Schwann cell interactions and forskolin

Since the mRNAs of the major myelin genes accumulate in parallel during the development of the PNS (Stahl et al., 1990; Snipes et al., 1992), we examined the expression of Cx32 mRNA by Northern blot analysis. In the sciatic nerve, the level of $\mathrm{P}_{0}$ mRNA increased dramatically after birth (Fig. 6). Reprobing the blot for Cx32 mRNA demonstrated that Cx32 mRNA changed during development in an identical pattern (the band indicated by the arrowhead in Fig. 6A), which is consistent with the idea that myelinating Schwann cells express Cx32 mRNA.

Since the maintenance of the myelinating phenotype, including the expression of high levels of myelin-related mRNAs, depends on the integrity of axon-Schwann cell interactions (Mirsky and Jessen, 1990; Scherer and Asbury, 1993), we examined 


\section{Transected}

\section{Crushed}

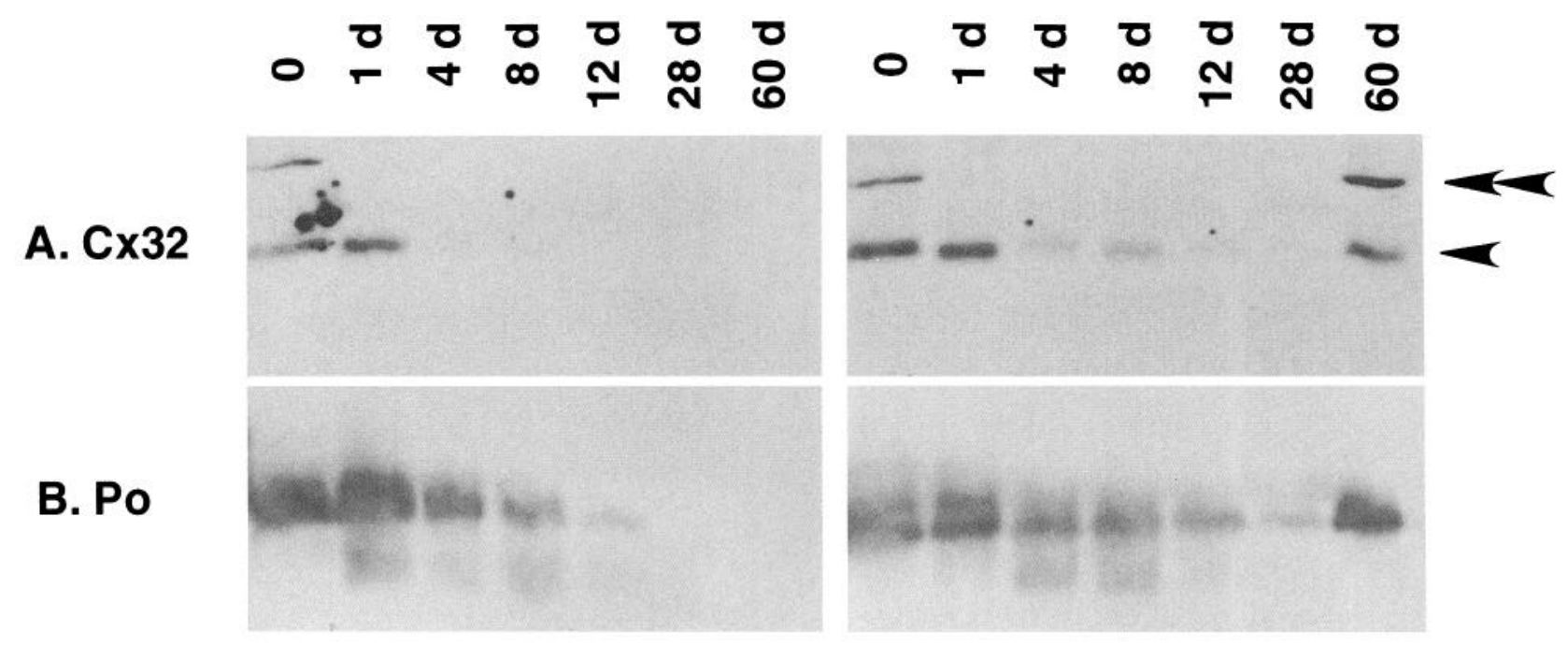

Figure 5. Western blot analysis of lesioned adult rat sciatic nerves. Each lane contains an equal amount ( $25 \mu \mathrm{g})$ of protein homogenate from the distal nerve-stumps of sciatic nerves $1,4,8,12,28$, or $60 \mathrm{~d}$ posttransection or crush; the " 0 " time point is from unlesioned nerves. The blots were hybridized together with a rabbit antiserum against rat Cx32, and then rehybridized with a rabbit antiserum against rat $P_{0}$. The blots were exposed to film for $30 \mathrm{~min}(C \times 32)$ or $1 \mathrm{sec}\left(P_{0}\right)$. The arrow marks the position of the $\mathrm{Cx} 32$ monomer, and the double arrowhead marks the position of the Cx32 dimer (Paul, 1986).

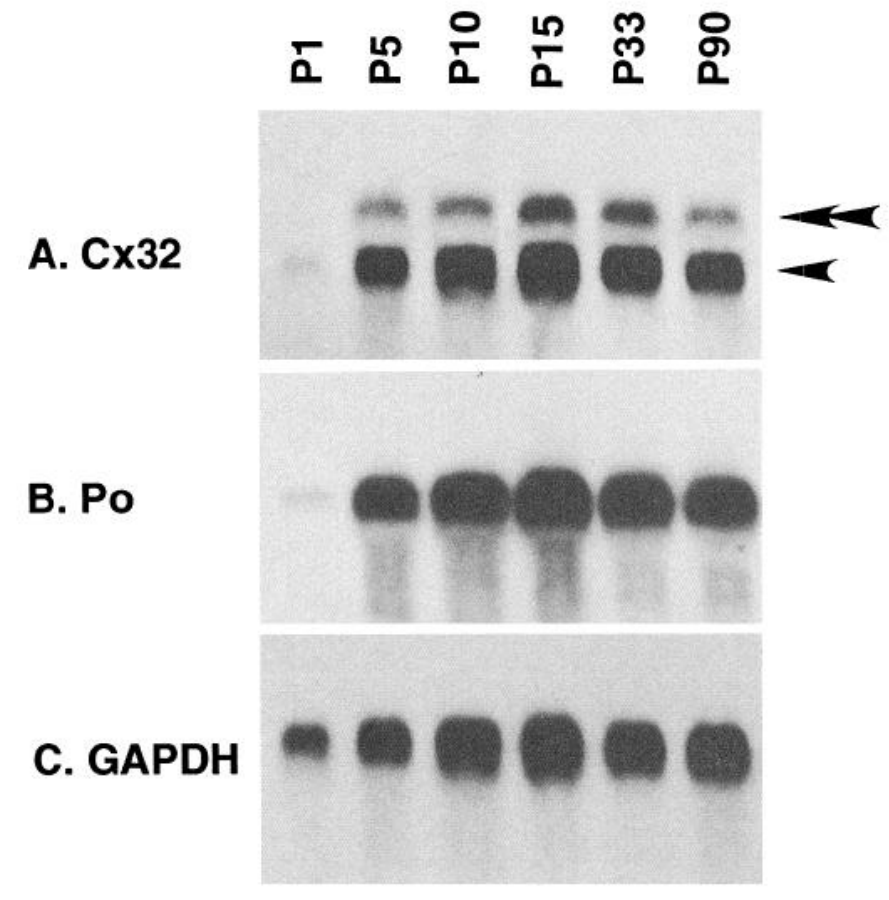

Figure 6. Northern blot analysis of developing sciatic nerve. Each lane contains an equal amount $(10 \mu \mathrm{g})$ of total RNA isolated from the distal stumps of sciatic nerves of various ages. The blots were successively hybridized with a radiolabeled cDNA probe for $\mathrm{P}_{0}(B), \mathrm{Cx} 32(A)$, and GAPDH $(C)$, and exposed to film for $3 \mathrm{hr}\left(P_{o}\right), 14 \mathrm{~d}(C \times 32)$, and $1 \mathrm{~d}(G A P D H)$, respectively. The arrowhead marks the Cx32 mRNA; the double arrowhead indicates the signal from the previous hybridization for $\mathrm{P}_{0}$ mRNA. the expression of $\mathrm{Cx} 32 \mathrm{mRNA}$ after permanent axotomy and nerve-crush. The distal nerve-stumps of crushed nerves were divided into a proximal and a distal segment, to facilitate the analysis of how changes in Schwann cell gene expression depend on regenerating axons, as axons regenerate in a proximal to distal manner. In permanently transected nerves, the level of Cx32 mRNA fell sharply between 1 and $8 \mathrm{~d}$ postlesion and did not return even by $58 \mathrm{~d}$ (Fig. 7). In crushed nerves, the level of Cx32 mRNA also fell between 1 and $8 \mathrm{~d}$ postlesion, but then increased. This increase was first seen in the proximal segment of the distal nerve-stump at $12 \mathrm{~d}$, and in the distal segment at $24 \mathrm{~d}$. Reprobing the blots demonstrated that the level of $\mathrm{P}_{0}$ mRNA in transected and crushed nerves followed essentially the same pattern as that of $\mathrm{Cx} 32$, except that the level of $\mathrm{P}_{0}$ mRNA fell more promptly than that of $\mathrm{Cx} 32$ (Fig. 7). Reprobing the blots for the low-affinity nerve growth factor receptor (NGFR) mRNA demonstrated a reciprocal pattern to that of $\mathrm{Cx} 32$ and $\mathrm{P}_{0}$, consistent with the evidence that myelinating Schwann cells do not express NGFR, whereas "denervated" Schwann cells express NGFR and not myelin-related genes (Mirsky and Jessen, 1990; Scherer and Asbury, 1993).

cAMP analogs mimick some of the effects of axon-Schwann cell interactions, such as increasing the expression of galactocerebroside, sulfatide, and $\mathrm{P}_{0}$, and inhibiting the expression of NGFR and GAP-43 (Sobue and Pleasure, 1984; Lemke and Chao, 1988; Morgan et al., 1991, 1994; Scherer et al., 1994). To determine whether cAMP would increase the level of Cx32 mRNA, we performed Northern blot analysis of cultured rat Schwann cells treated for $3 \mathrm{~d}$ with $4 \mu \mathrm{M}$ forskolin, an activator of adenylate cyclase (Seamon et al., 1981). As shown in Figure 8 , forskolin increased the levels of $\mathrm{Cx} 32$ and $\mathrm{P}_{0} \mathrm{mRNA}$, but the level was not as high as in unlesioned sciatic nerve. Cultured perineurial fibroblasts, which are the other major cell type in peripheral nerve and coupled by gap junctions (Reale et al., 1975; Schiavinato et al., 1991), did not express Cx32 mRNA 
Transected
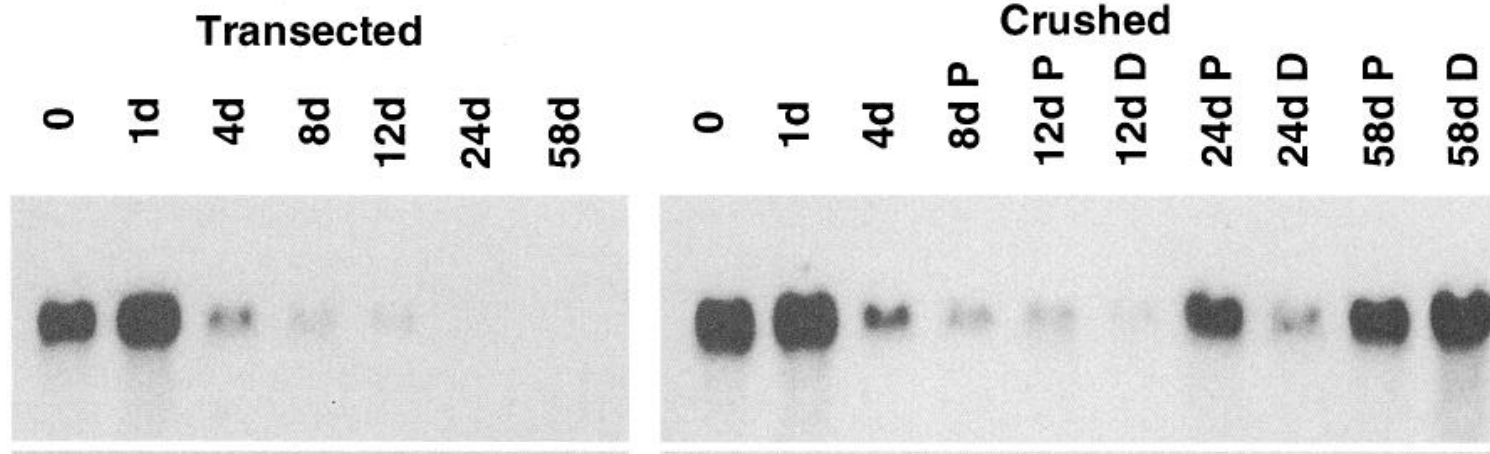

A. $\mathrm{Cx} 32$

B. Po

C. NGFR
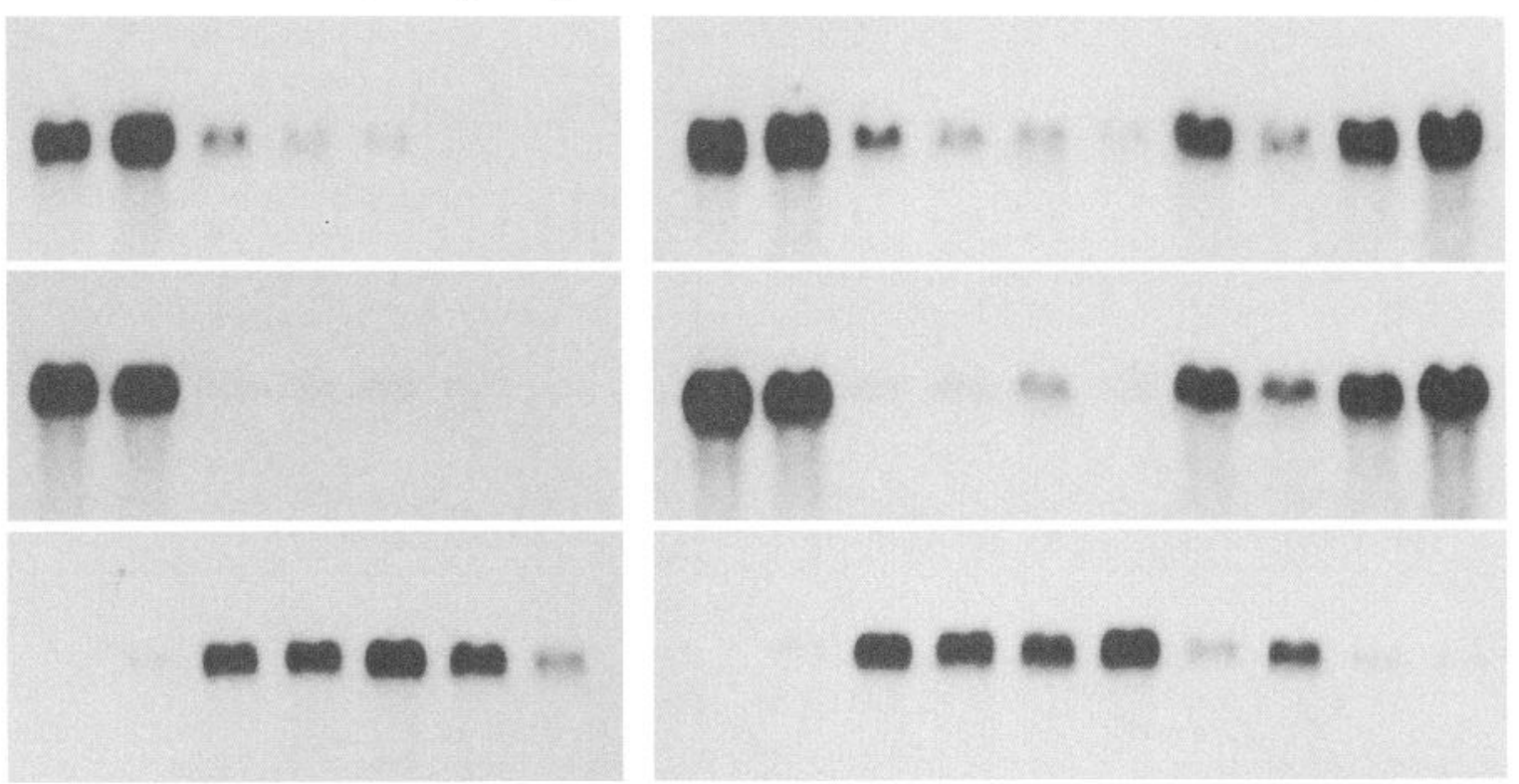

D. GAPDH

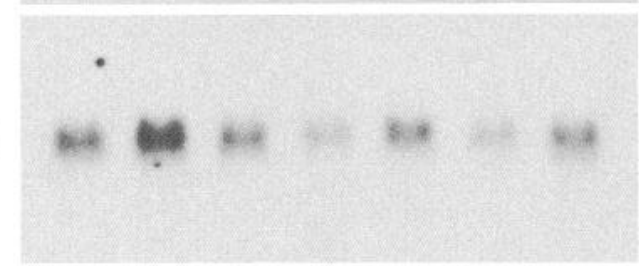

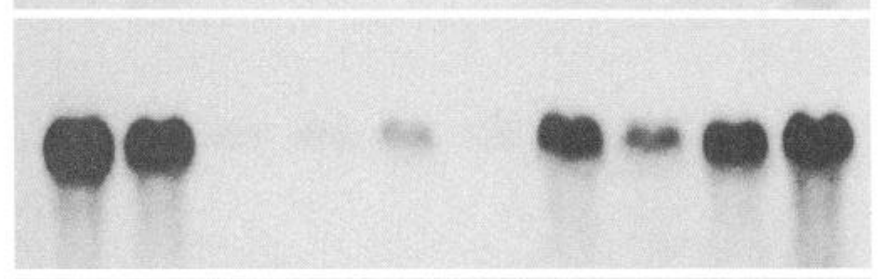

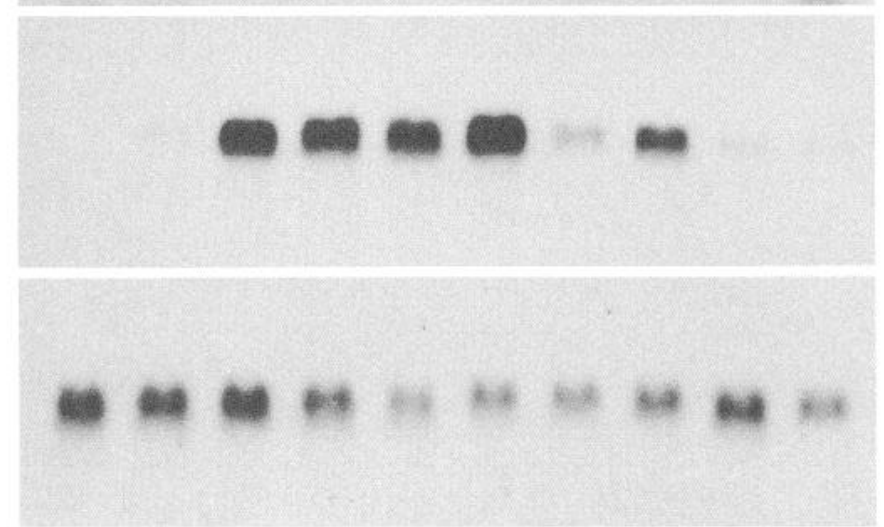

Figure 7. Northern blot analysis of normal and lesioned adult rat sciatic nerves. Each lane contains an equal amount (10 $\mu \mathrm{g})$ of total RNA isolated from the distal stumps of sciatic nerves that had been transected or crushed. The number of days after each of these lesions in indicated; the " 0 " time point is from unlesioned nerves. In crushed nerves, the distal nerve-stumps were divided into proximal $(P)$ and distal $(D)$ segments of equal lengths. The blots were successively hybridized with a radiolabeled cDNA probe for Cx32 $(A), \mathrm{P}_{0}(B)$, NGFR $(C)$, and GAPDH $(D)$, and exposed to film for $14 \mathrm{~d}(\mathrm{Cx} 32), 2 \mathrm{hr}\left(\mathrm{P}_{0}\right), 1 \mathrm{~d}$ (NGFR), and $3 \mathrm{~d}(\mathrm{GAPDH})$, respectively.

even when treated with forskolin, but did express Cx43 mRNA (Fig. 8). To determine whether forskolin increased the expression of Cx32 protein, we prepared Western blots of Schwann cells that had been treated for $3 \mathrm{~d}$ with 0,4 , or $20 \mu \mathrm{M}$ forskolin. We did not detect $\mathrm{Cx} 32$ in either untreated or treated Schwann cells, whereas reprobing the blot for $\mathrm{P}_{0}$ demonstrated a robust increase in $\mathrm{P}_{0}$ protein in forskolin-treated cells (data not shown). Thus, forskolin increases the expression of Cx32 mRNA in a similar manner to other myelin-related genes.

\section{Connexin32 is expressed by oligodendrocytes}

Although $\mathrm{Cx} 32$ has been reported to be expressed by oligodendrocytes and neurons (Dermietzel et al., 1989; Micevych and Abelson, 1991; Yamamoto et al., 1991; Robinson et al., 1993), the clinical data indicate that CMTX patients do not usually have CNS abnormalities (Phillips et al., 1985; Rozear et al., 1987; Hahn et al., 1990; Ionasescu et al., 1992). Hence, even though Schwann cells and oligodendrocytes both express Cx32 and are the sole myelin-forming cells, oligodendrocytes may not be affected by mutations of $\mathrm{Cx} 32$.

We examined the expression of $\mathrm{Cx} 32$ in the developing rat spinal cord, which contains a number of tracts that myelinate at different times in postnatal development (Schwab and Schnell,
1989; Baron et al., 1993). At P1, Cx32 colocalized with MAG and PLP in the cell bodies of developing oligodendrocytes (data not shown). In adult spinal cord, the most prominent $\mathrm{Cx} 32$-immunoreactivity was found in the cell bodies and processes of oligodendrocytes, but the myelin sheaths themselves were not stained (Fig. 9A,C). To confirm and extend these findings, we double-labeled sections for $\mathrm{Cx} 32$ and MAG and for $\mathrm{Cx} 32$ and myelin-oligodendrocyte glycoprotein (MOG), as MAG and MOG are localized to the adaxonal and abaxonal surfaces of the myelin sheath, respectively (Sternberger et al., 1979; Brunner et al., 1989). Cx32 colocalized with MAG in oligodendrocyte cell bodies, but $\mathrm{Cx} 32$ labeling did not colocalize with that of MAG at the adaxonal surface of oligodendrocytes (data not shown). $\mathrm{Cx} 32$ colocalized with MOG in some oligodendrocyte processes, but the adaxonal surface of the myelin sheath was mostly Cx32negative (Fig. 9). Thus, while Cx32 is a myelin-related protein in the PNS and CNS, it is distributed in different aspects of the myelinating cell.

The localization of Cx32 in the spinal cord suggested that it predominately expressed by oligodendrocytes. Since the onset and tempo of myelination in the CNS differ in the various myelinated fiber tracts of the CNS (Jacobson, 1963; Cohen and Guarnieri, 1976), we examined the accumulation of $\mathrm{Cx} 32$ pro- 
$\mathrm{Fb}$

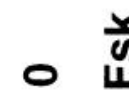

\section{A. $\mathrm{Cx32}$}

\section{B. Po}

\section{C. $\mathrm{Cx43}$}

D. GAPDH

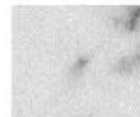

SC

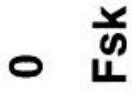

象
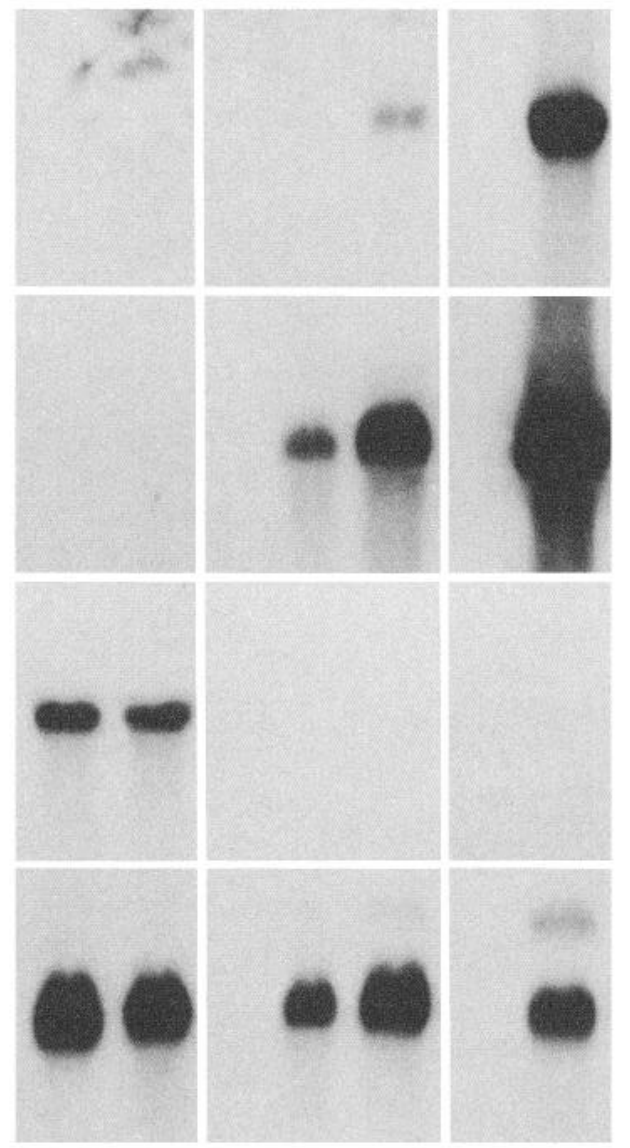

Figure 8. Northern blot analysis of cultured Schwann cells and fibroblasts. Each lane contains an equal amount $(30 \mu \mathrm{g})$ of total RNA isolated from Schwann cells or fibroblasts cultured for $3 \mathrm{~d}$ in the absence (lane 0 ) or presence of $4 \mu \mathrm{M}$ forskolin. For comparison, a sample of normal sciatic nerve RNA was run in an adjacent lane (marked $S N$ ). The blot was successively hybridized with a radiolabeled cDNA probe for $\mathrm{Cx} 32(A), \mathrm{P}_{0}(B), \mathrm{GAPDH}(D)$, and $\mathrm{Cx} 43(C)$, and exposed to film for $12 \mathrm{~d}(\mathrm{Cx} 32), 2 \mathrm{hr}\left(\mathrm{P}_{0}\right), 4 \mathrm{~d}(\mathrm{Cx} 43)$, and $3 \mathrm{~d}(\mathrm{GAPDH})$.

tein in different CNS regions by Western blot analysis. Protein homogenates of spinal cord, brainstem, cerebellum, and cerebrum were prepared from rats of various ages, from P1 to P90. The blots were probed with a rabbit antiserum against $\mathrm{Cx} 32$, then the same blots were reprobed with a rabbit antiserum against PLP. Cx32 and PLP were more abundant in the brainstem and spinal cord (Fig. 10) than in the cerebrum and cerebellum (not shown), and the amount of Cx32 and PLP in each brain region increased from P1 to P90 (Fig. 10). We also made a myelin preparation of adult cerebrum, brainstem, and spinal cord, to enrich for membrane-related proteins, in order to compare the amount of $\mathrm{Cx} 32$ in the myelin fractions to that in homogenates of the corresponding brain regions. Western blot analysis demonstrated that in each brain region, the myelin fraction contained relatively more $\mathrm{Cx} 32$, and that PLP was enriched to a similar extent (Fig. 10). These results demonstrate that $\mathrm{Cx} 32$ accumulates in parallel with other myelin proteins during development.

\section{Cx32 mRNA is expressed in concert with other myelin-related genes in oligodendrocytes}

Like the myelin proteins, the myelin-related mRNAs accumulate in parallel during the development of the CNS, with modest differences between different brain regions (Kanfer et al., 1989; Scherer et al., 1994). Thus, we compared the expression of Cx32 mRNA in the cerebrum, cerebellum, and brainstem to that of PLP (Fig. 11). In each region, the levels of Cx32 and PLP mRNA were parallel, with a similar onset and peak. Prolonged overexposure of the blot demonstrated, however, a low level of Cx32 mRNA expression prior to the onset of PLP mRNA expression (data not shown), consistent with the idea that neurons express Cx32 prior to oligodendrocytes.

The above findings indicate that most of the Cx32 mRNA in the CNS originates from oligodendrocytes, which is consistent with the in situ hybridization localization of Cx32 mRNA in adult rat CNS (Micevych and Abelson, 1991). To further substantiate this idea, we analyzed Cx32 mRNA expression in myelin-deficient rats and jimpy mice, which have mutations in the PLP gene, and drastically reduced levels of all myelin-related mRNAs (Hudson, 1990). Northern blot analysis of affected male myelin-deficient rats and their age-matched normal male littermates revealed that affected males had much lower levels of Cx32 mRNA at every age (Fig. 12). The levels of Cx32 mRNA in the brains of jimpy mice were also much lower than those in the brains of age-matched normal mice as well as shiverer mice, which have a recessively inherited mutation in the MBP gene (Hudson, 1990). Reprobing the blots for PLP mRNA demonstrated that the levels of PLP mRNA were much lower at every age in both myelin-deficient rats and jimpy mice than in nonmutant animals and shiverer mice (Fig. 12). The changes in myelin-related mRNA expression in the mutant animals were not confined to Cx32 and PLP, as MBP and MAG are similarly affected (data not shown; see also Roth et al., 1985; Gardinier and Macklin, 1988; Kumar et al., 1988; Kumar et al., 1990; Macklin et al., 1991). Thus, the parallel reduction in Cx32 mRNA and other myelin-related mRNAs in these PLP mutants provides strong evidence that most Cx32 mRNA in the CNS is derived from oligodendrocytes.

\section{Discussion}

The finding that mutations in Cx32 cause CMTX (Bergoffen et al., 1993) led us to investigate the role of $\mathrm{Cx} 32$ in myelinating glia. In this article, we have shown that $\mathrm{Cx} 32$ is expressed in myelinating Schwann cells and oligodendrocytes, but is localized to different parts of each cell. In the PNS, Cx32 is found mainly in the incisures and paranodal regions of myelinating Schwann cells, whereas in the CNS, it is found in oligodendrocyte cell bodies and processes. In both Schwann cells and oligodendrocytes, $\mathrm{Cx} 32$ protein and mRNA are expressed in a coordinate manner with those of other myelin genes. In Schwann cells, the expression of Cx32 mRNA and protein is developmentally regulated and depends on the integrity of axonSchwann cell interactions. In oligodendrocytes, $\mathrm{Cx} 32$ is expressed in concert with other myelin genes, both in normal development and in jimpy mice and myelin-deficient rats. Thus, $\mathrm{Cx} 32$ is expressed as part of the myelinating phenotype of both Schwann cells and oligodendrocytes. 

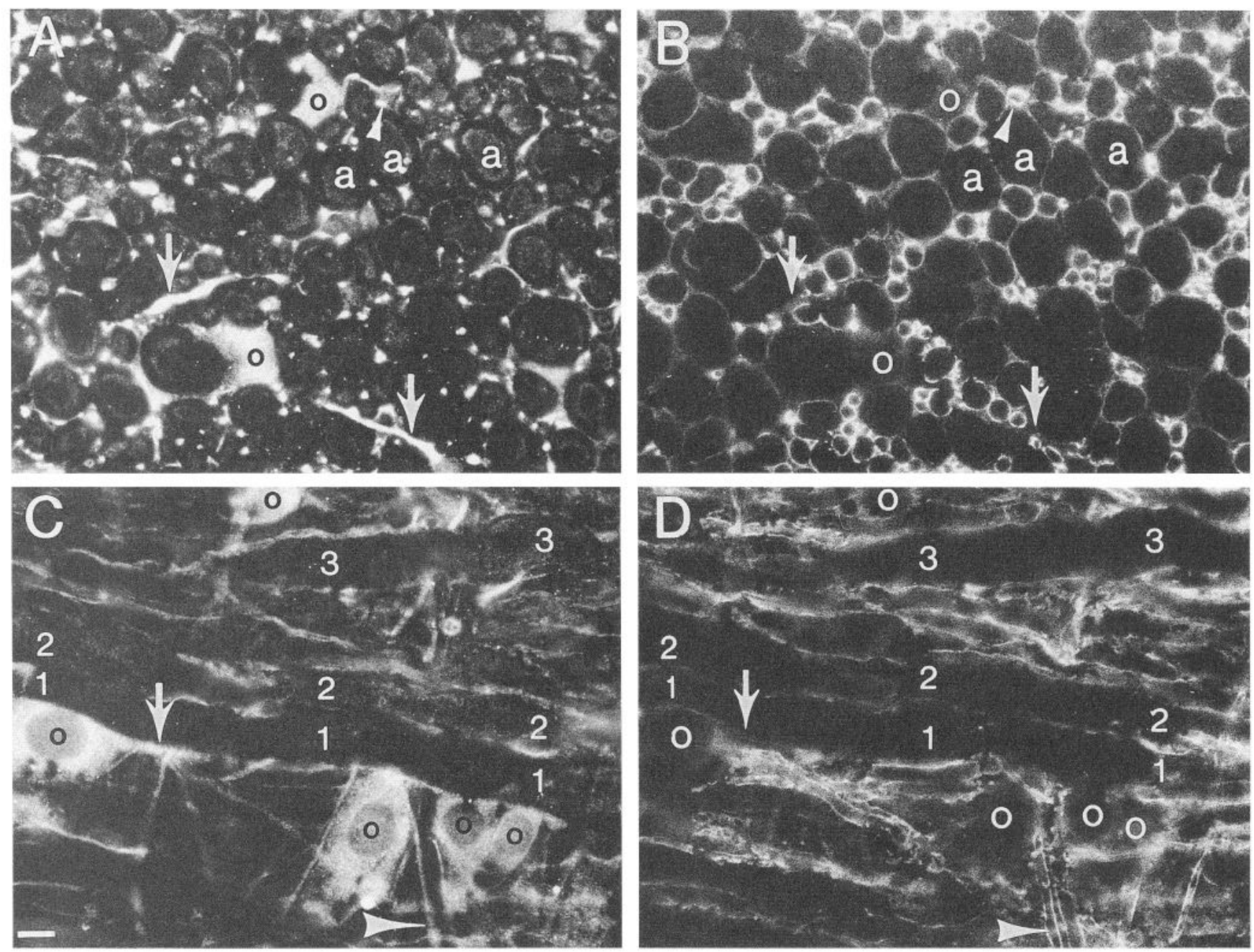

Figure 9. Immunohistochemical analysis of $\mathrm{Cx} 32$ in the ventral funiculus of adult rat spinal cord. These are photomicrographs of transverse (A,B) and longitudinal sections $(C, D)$, double-labeled with a rabbit antiserum against $\mathrm{Cx} 32(A, C)$ and a mouse monoclonal antibody against MOG ( $B, D)$, and visualized with rhodamine-/and fluorescein-coupled secondary antibodies, respectively. Cx32-immunoreactivity is found in oligodendrocytes $(o)$ and their processes, some of which are indicated by arrows. MOG-immunoreactivity is found on the external/abaxonal surface of the myelin sheath, around a few oligodendrocyte processes (arrowheads), but not in the oligodendrocytes themselves (o). Some myelinated axons are indicated ( $a$ in $A$ and $B$ and $1,2,3$ in $C$ and $D$ ); the myelin sheath is unlabeled by Cx32 or MOG. Scale bar, $10 \mu \mathrm{m}$.

\section{Gap junctions in Schwann cells}

Since Cx32 forms gap junctions in many tissues, its localization in the incisures and paranodal regions indicates that gap junctions should be found at these locations. Small collections of hexagonally packed particles of the appropriate size to be gap junctions have been found in the incisures and paranodes of the PNS myelin sheath by freeze-fracture electron microscopy (Sandri et al., 1982). As these collections of particles seen by freezefracture are characteristic of gap junctions, and $\mathrm{Cx} 32$ is found at these same sites, it is reasonable to propose that these gap junctions contain $\mathrm{Cx} 32$. Since they link apposed layers of the same cell, these could be called "reflexive" gap junctions, which have also been described in the kidney and other tissues (Majack and Larsen, 1980). Why typical gap junctions have not been noted in incisures and paranodes is unclear, as these structures have been extensively studied by transmission electron microscopy (Thomas and Ochoa, 1984; Peters et al., 1991).

More typical gap junctions, between different Schwann cells, have also been described. Electrophysiological recordings and tracer studies have revealed gap junctions between nonmyeli- nating Schwann cells (but not between myelinating Schwann cells) in peripheral nerve (Konishi, 1990). In peripheral nerve undergoing Wallerian degeneration, gap junctions between adjacent Schwann cells have been observed by transmission electron microscopy (Tetzlaff, 1982), and there existence has also been inferred by recent electrophysiological observations (Brunet and Jirounek, 1994). Finally, gap junctions have been observed between rat Schwann cells cultured in the absence of forskolin (Chanson et al., 1993). The connexin(s) that forms gap junctions between nonmyelinating, denervated, and cultured rat Schwann cells has not been identified. Since Cx32 appears to be expressed by nonmyelinating Schwann, it may form the gap junctions in these cells. The connexin expressed by Schwann cells cultured in the absence of forskolin is unlikely to be $\mathrm{Cx} 32$, which we find to be expressed at very low levels under these conditions, and which has different electrophysiological properties than those described by Chanson et al. (1993).

How do CMTX mutations cause neuropathy?

Many different mutations in the $\mathrm{Cx} 32$ gene cause CMTX. To date, 33 different mutations, affecting nearly every portion of 

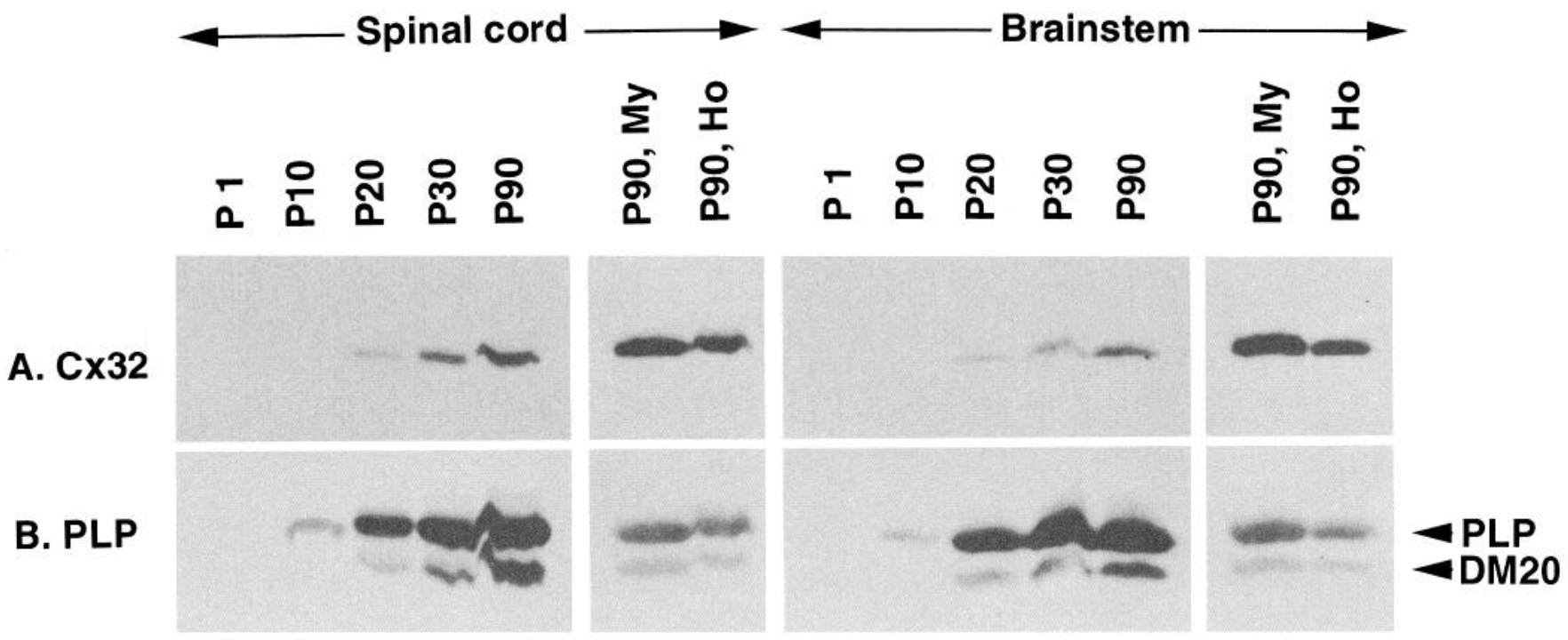

Figure 10. Western blot analysis of Cx32 in the CNS. Each lane contains $25 \mu \mathrm{g}$ of protein homogenate (Ho) from developing rat spinal cord or brainstem at the indicated ages, or from a myelin preparation $(\mathrm{My})$ of adult rat spinal cord or brainstem. The blots were hybridized with a rabbit antiserum against rat $\mathrm{Cx} 32$, then rehybridized with a rabbit antiserum against rat PLP. The blots of developing spinal cord and brainstem were hybridized together and exposed to film for $5 \mathrm{~min}(\mathrm{Cx} 32)$ and $1 \mathrm{~min}(\mathrm{PLP})$. The blots of spinal cord and brainstem myelin were hybridized together and exposed to film for $3 \mathrm{~min}(\mathrm{Cx} 32)$ and $10 \mathrm{sec}(\mathrm{PLP})$. The arrowheads indicate the position of PLP and its alternatively spliced isoform, DM20.

the Cx32 protein, have been found in 39 kindreds (Bone et al., 1995). To determine whether these mutations result in a loss of function, Bruzzone et al. (1994) expressed three different CMTX genes, as well as the wild-type Cx32 gene, in Xenopus oocytes. Whereas the wild-type $\mathrm{Cx} 32$ formed gap junctions, no oocytes expressing any of the three CMTX cDNAs formed functional gap junctions with oocytes expressing Cx26 or wild-type Cx32. Using a similar approach, Rabadan-Diehl and colleagues (1994) found that another CMTX mutation (Arg $200 \rightarrow$ stop codon) did not destroy channel activity, indicating that CMTX mutations may disrupt gap junctions in other ways besides a simple loss of function. To determine whether $\mathrm{Cx} 32$ mutations could also have a dominant-negative effect, Bruzzone et al. (1994) coinjected the same three CMTX mutations described above with wild-type $\mathrm{Cx} 26$, which is often coexpressed with $\mathrm{Cx} 32$ (Nicholson et al., 1987; Meda et al., 1993; Zhang and Nicholson, 1994). Oocytes that were coinjected with wild-type Cx26 and wild-type Cx32 cDNAs formed gap junctions when apposed to oocytes that expressed wild-type Cx26 cDNA (Barrio et al., 1991). Oocytes that were coinjected with wild-type Cx26 and the CMTX mutations, however, showed decreased junctional conductance (Bruzzone et al., 1994). These data suggest that

Brainstem

Cerebellum

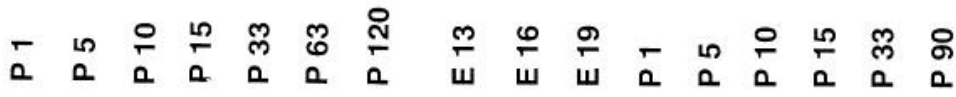

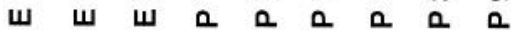

A. $\mathrm{C} \times 32$

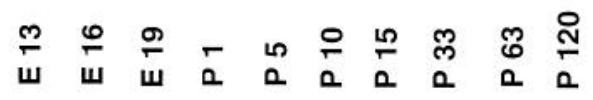

B. PLP
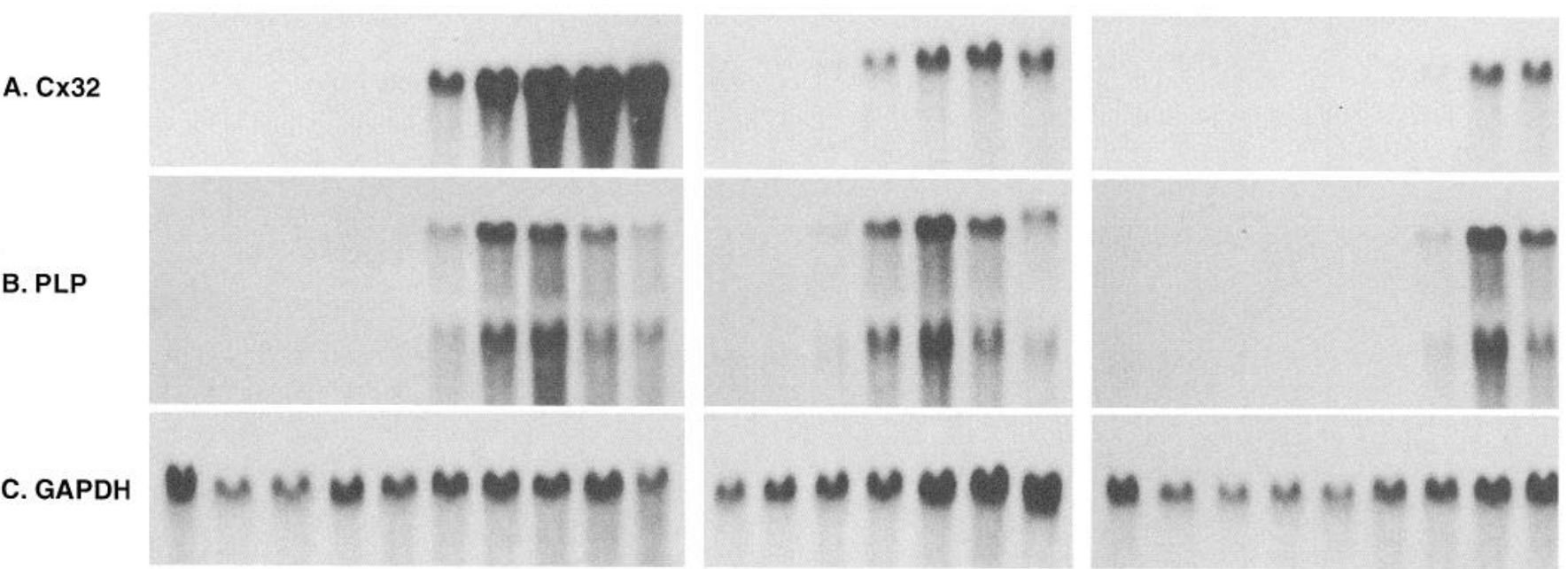

Figure 11. Northern blot analysis of Cx32 mRNA in developing brain. Each lane contains an equal amount (10 $\mu \mathrm{g})$ of total RNA isolated from the cerebrum, cerebellum, and brainstem. The blots were successively hybridized with a radiolabeled cDNA probe for Cx32 $(A)$, PLP $(B)$, and GAPDH $(C)$, and exposed to film for $15 \mathrm{~d}(\mathrm{Cx} 32), 2 \mathrm{hr}$ (PLP), and $16 \mathrm{hr}$ (GAPDH), respectively. 
normal md shiverer jimpy normal

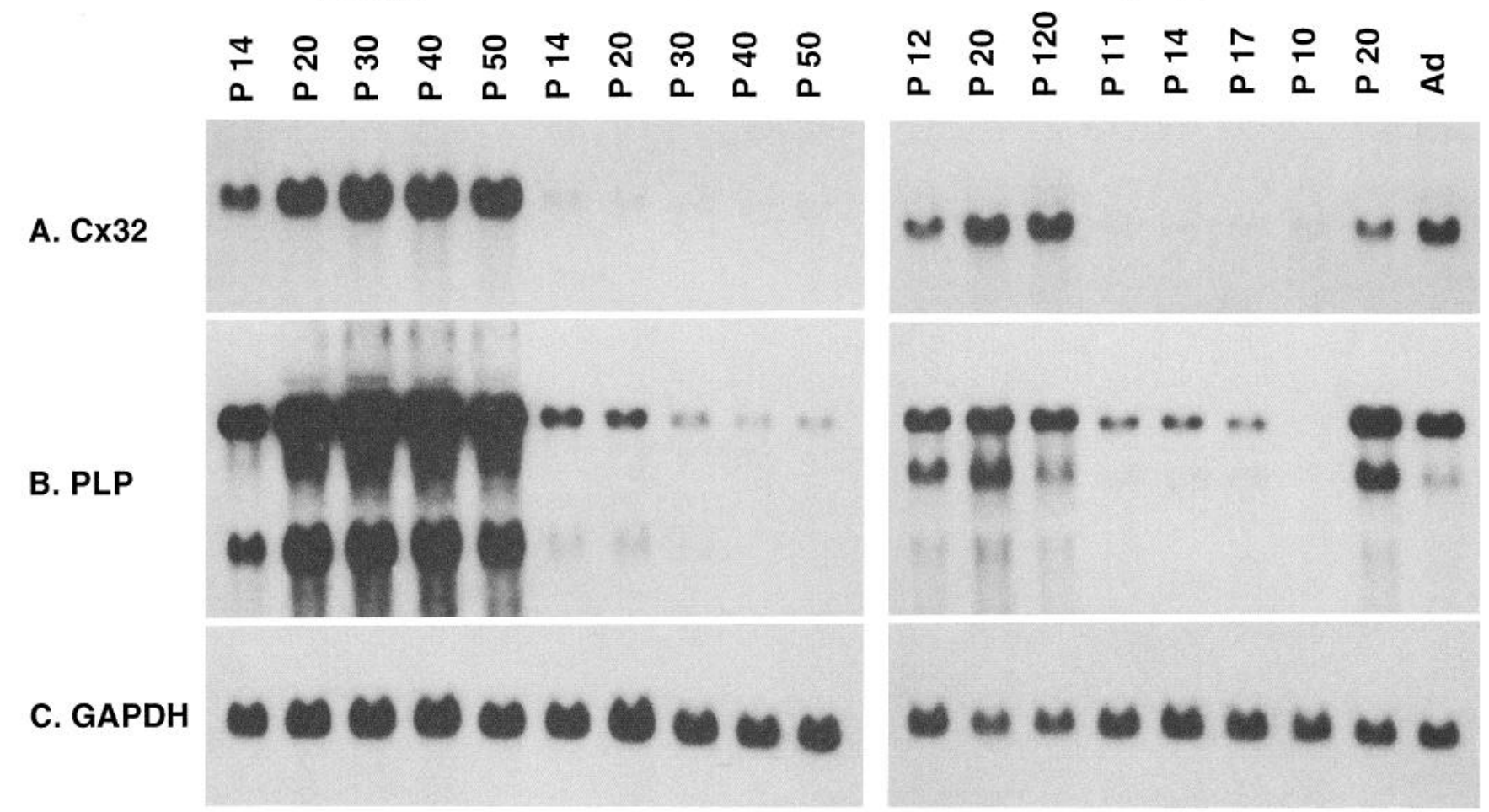

Figure 12. Northern blot analysis of Cx32 mRNA expression in the brains of myelin mutants. Each lane contains an equal amount (10 $\mu \mathrm{g})$ of total RNA isolated from the whole brains (cerebrum, cerebellum, and brainstem) of individual animals of the indicated ages-myelin-deficient rats and their normal littermates, shiverer mice, and jimpy mice. RNA from cerebra of normal mice is shown for comparison. The blots were successively hybridized together with a radiolabeled cDNA probe for Cx32 (A), PLP $(B)$, and GAPDH $(C)$, and exposed to film for 14 d (Cx32), $1 \mathrm{~d}$ (PLP), and $16 \mathrm{hr}(\mathrm{GAPDH})$, respectively. Note that in rats, the major PLP transcripts in rats are 3.2 and $1.6 \mathrm{~kb}$; in mice, 3.2 and $2.8 \mathrm{~kb}$ are main transcripts.

many CMTX mutations cause a loss of functional Cx32 protein, and that at least some CMTX mutations can also have a dominant-negative effect. Yet, in spite of the large number of different mutations, and the evidence that different mutations may have different functional effects, there is no compelling evidence that different mutations cause different clinical phenotypes.

The localization of $\mathrm{Cx} 32$ in the Schwann cell myelin sheath, and the loss of function of CMTX mutations in oocytes, strongly suggest that at least some CMTX mutations cause a loss of functional gap junctions in the incisures and paranodes. Why these gap junctions are critical to the normal health of myelinated axons, however, remains to be determined. One potentially important consideration is that the geometry of the myelin sheath itself. Myelin is a fundamental adaptation of jawed vertebrates, and is formed by the enormous expansion of Schwann cell and oligodendrocyte membrane (Peters et al., 1991). Gap junctions in the paranodes and incisures would allow ions and small molecules to diffuse radially, directly tranversing the myelin sheath, instead of circumferentially through the Schwann cell cytoplasm, which would be a much longer pathway. In the largest myelin sheaths of mammals, this potential radial pathway would be more than 1000-fold shorter than the circumferential pathway, as the unrolled myelin sheath is more than $4 \mathrm{~mm}$ long, whereas the compact myelin sheath is less than $4 \mu \mathrm{m}$ thick (Friede and Bischhausen, 1980). If CMTX mutations interrupt the function of these gap junctions, then this radial pathway would be abolished. At this time, we can only speculate as to what are the crucial molecules that pass through these gap junctions, or even whether the interruption of diffusion towards or away from the axon is more important.

A related issue is why mutations of Cx32 selectively affect myelinating Schwann cells. Patients who have CMTX have not been reported to have significant abnormalities in other tissues that express $\mathrm{Cx} 32$. The level of $\mathrm{Cx} 32$ expression does not seem to be critical, as several tissues, such as the brain and spleen, express levels of Cx32 mRNA that are comparable to peripheral nerve, and liver expresses much higher levels (Nishi et al., 1991; Bergoffen et al., 1993; Meda et al., 1993). Myelinating Schwann cells may be uniquely susceptible to $\mathrm{Cx} 32$ mutations because Cx32 is the only connexin they express. In support of this idea, we have not detected $\mathrm{Cx} 43, \mathrm{Cx} 40$, or $\mathrm{Cx} 26 \mathrm{mRNA}$ in rat Schwann cells treated with forskolin (Fig. 8 and data not shown). Cultured sciatic fibroblasts express Cx43 mRNA (Fig. 8 ), and adult sciatic nerve expresses a low level of Cx43 mRNA that is not modulated by axotomy (data not shown), indicating Cx43 mRNA in nerve is derived from fibroblasts and not myelinating Schwann cells. On the other hand, there is a growing body of evidence that most cell types express more than one connexin. The liver, for example, expresses Cx32 and Cx26 (Nicholson et al., 1987; Meda et al., 1993; Kuraoka et al., 1993), and epidermal cells express four different connexins (Goliger and Paul, 1994).

\section{Cx32 in CNS myelin}

Patients who have CMTX are not known to have CNS abnormalities, although oligodendrocytes, the only other myelin-form- 
ing cells, have been reported to express Cx32 mRNA and protein (Dermietzel et al., 1989; Micevych and Abelson, 1991). In agreement with previous reports (Naus et al., 1990; Belliveau et al., 1991), we found regional and developmental differences in the expression of Cx32 mRNA. We extended these observations by demonstrating a close association between Cx32 mRNA expression and that of other myelin genes, both in normal development and in PLP mutants. Western blot analysis of Cx32 also demonstrated regional and developmental differences, as well as decreased expression in PLP mutants. Cx32 protein was more abundant in the pons and spinal cord than in the cerebrum and cerebellum, and the amount of protein accumulated in parallel with PLP. These results differ from those of Belliveau et al. (1991), who did not find a developmental increase in Cx32 protein in the cerebrum or hindbrain. The good agreement between the levels of Cx32 mRNA and protein both in development and in PLP mutants, nevertheless, indicates that most of the $\mathrm{C} \times 32$ mRNA and protein in the CNS is derived from oligodendrocytes.

The localization of $\mathrm{Cx} 32$ in oligodendrocytes has received relatively little attention. Several workers have examined the localization of $\mathrm{Cx} 32$ in the neurons of the spinal cord without mentioning oligodendrocyte labeling (Carr et al., 1991; Yamamoto et al., 1991). Dermietzel et al. (1989) reported Cx32-immunoreactivity in the perinuclear region of oligodendrocytes, but did not systemically evaluate the localization of $\mathrm{Cx} 32$ during development. We found that in older animals, Cx32 is predominately found in cell bodies and processes, and was not found in compact myelin, in contrast to the recent report of Spray and Dermietzel (1995). These observations generally agree with the localization of gap junctions in by treeze-fracture electron microscopy (Massa and Mugnaini, 1982; Sandri et al., 1982; Robinson et al., 1993). Whether Cx32 is also found in the paranodal regions of CNS myelin sheaths, which contains gap junctions by freeze-fracture, remains to be determined.

\section{References}

Aguayo AJ, Epps J, Charron J, Bray GM (1976) Multipotentiality of Schwann cells in cross-anastomosed and grafted unmyelinated nerves-quantitative microscopy and radioautography. Brain Res 104:1-20.

Apostolski S, Sadiq SA, Hays A, Corbo M, Suturkova L, Chaliff P, Stefansson K, LeBaron RG, Ruoslahti E, Hays AP, Latov N (1994) Identification of $\mathrm{Gal}(\beta 1-3) \mathrm{GalNAc}$ bearing glycoproteins at the nodes of Ranvier in peripheral nerve. J Neurosci Res 38:134-141.

Archelos JJ, Roggenbuck K, Schneider-Schaulies J, Linington C, Toyka KV, Hartung HP (1993) Production and characterization of monoclonal antibodies to the extracellular domain of PO. J Neurosci Res 35:46-53.

Baron P, Kamholz J, Scherer S, Honda H, Shy M, Scarpini E, Scarlato G, Pleasure D (1993) Appearance of PLP mRNA in specific regions of the developing rat lumbosacral spinal cord as revealed by in situ hybridization. Exp Neurol 121:139-147.

Barrio LC, Suchyna T, Bargiello T, Xu LX, Roginski RS, Bennett MVL, Nicholson BJ (1991) Gap junctions formed by connexins 26 and 32 alone and in combination are differently affected by applied voltage. Proc Natl Acad Sci USA 88:8410-8414.

Belliveau DJ, Kidder GM, Vaus CCG (1991) Expression of gap junction genes during postnatal neural development. Dev Genet 12:308317.

Bennett MVL, Barrio LC, Bargiello TA, Spray DC, Hertzberg E, Saez JC (1991) Gap junctions: new tools, new answers, new questions. Neuron 6:305-320.

Bergoffen J, Scherer SS, Wang S, Oronzi-Scott M, Bone L, Paul DL, Chen K, Lensch MW, Chance P, Fischbeck K (1993) Connexin mutations in X-linked Charcot-Marie-Tooth disease. Science 262:2039. 2042.
Bone LJ, Dahl N, Lensch MW, Chance PF, Kelly T, Le Gucrn E, Magi S, Parry G, Shapiro H, Wang S, Fischbeck KH (1995) New connexin32 mutations associated with $\mathrm{X}$-linked Charcot-Marie-Tooth disease. Neurology, in press.

Brockes JP, Fields P, Raff MC (1979) Studies on cultured rat Schwann cells. I. Establishment of purified populations from cultures of peripheral nerve. Brain Res 165:105-118.

Brockes JP, Lemke GE, Balzer DR Jr (1980) Purification and preliminary characterization of a glial growth factor from the bovine pituitary. J Biol Chem 255:8374-8377.

Brunet PC, Jirounek P (1994) Long-range intercellular signalling in glial cells of the peripheral ncrve. Ncuroreport 5:635-638.

Brunner C, Lassmann $\mathrm{H}$, Waehneldt TV, Matthieu J-M, Linington C (1989) Differential ultrastructural localization of myelin basic protein, myelin/oligodendrocyte glycoprotein, and $2^{\prime}, 3^{\prime}$-cyclic nucleotide $3^{\prime}$-phosphodiesterase in the CNS of adult rats. J Neurochem 52:296304.

Bruzzone R, White TW, Scherer SS, Fischbeck KH, Paul DL (1994) Null mutations of connexin 32 in patients with X-linked Charcot-Marie-Tooth disease. Neuron 13:1253-1260.

Carr PA, Yamamoto T, Karmy G, Nagy JI (1991) Cytochemical relationships and central terminations of a unique population of primary afferent neurons in rat. Brain Res Bull 26:825-843.

Chance PF, Pleasure D (1993) Charcot-Marie-Tooth syndrome. Arch Neurol 50:1180-1183.

Chanson M, Chandross KJ, Kook MB, Kessler JA, Spray DC (1993) Gating characteristics of a steeply voltage-dependent gap junction channel in rat Schwann cells. J Gen Physiol 102:925-946.

Chirgwin JM, Przbyla AE, MacDonald RJ, Rutter RJ (1979) Isolation of biologically active ribonucleic acid from sources enriched in ribonuclease. Biochemistry 18:5294-5299.

Cohen R, Guarnieri M (1976) Immunochemical measurement of myelin basic protein in developing rat brain: an index of myelin synthesis. Dev Biol 49:294-299.

Curtis R, Stewart HJS, Hall SM, Wilkin GP, Mirsky R, Jessen KR (1992) GAP-43 is expressed by nonmyelin-forming Schwann cells of the peripheral nervous system. J Cell Biol 116:1455-1464.

DeFerra F, Engh H, Hudson L, Kamholz J, Puckett C, Molineaux S, Lazzarini RA (1985) Alternative splicing accounts for the four forms of myelin basic protein. Cell 43:721-727.

Dermietzel R, Hwang TK, Spray DS (1990) The gap junction family: structure, function and chemistry. Anat Embryol 182:517-528.

Dermietzel R, Traub O, Hwang TK, Beyer E, Bennett MVL, Spray DC, Willecke K (1989) Differential expression of three gap junction proteins in developing anId mature brain tissues. Proc Natl Acad Sci USA 86:10148-10152.

D'Urso D, Brophy PJ, Staugaitis SM, Gillespie CS, Frey AB, Stempak JG, Colman DR (1990) Protein zero of peripheral nerve myelin: biosynthesis, membrane insertion, and evidence for homotypic interaction. Neuron 4:449-460.

Fannon AM, Sherman DL, Ilyina-Gragerova G, Brophy PJ, Friedrich VL, Colman DR (1995) Novel E-cadherin mediated adhesion in peripheral nerve: Schwann cell architecture is stabilized by autotypic adherens junctions. J Cell Biol 129:189-202.

Fort P, Marty L, Piechaczyk M, Sabrouty SE, Dani C, Jeanteur P, Blanchard JM (1985) Various rat adult tissues express only one major mRNA species from the glyceraldehyde-3-phosphate-dehydrogenase multigenic family. Nucleic Acids Res 13:1431-1442.

Friede RL, Bischhausen R (1980) The precise geometry of large internodes. J Neurol Sci 48:367-381.

Friedman B, Zaremba S, Hockfield S (1990) Monoclonal antibody rat 401 recognizes Schwann cells in mature and developing peripheral nerve. J Comp Neurol 295:43-57.

Gardinier MV, Macklin WB (1988) Myelin proteolipid protein gene expression in jimpy and jimpy ${ }^{\mathrm{msd}}$ mice. $\mathrm{J}$ Neurochem $51: 360-364$.

Goliger JA, Paul DL (1994) Expression of gap junction proteins Cx26, Cx31.1, Cx37, and Cx43 in developing and mature rat epidermis. Dev Dynam 200:1-13.

Goodenough DA, Paul DL, Jesaitis L (1988) Topological distribution of two connexin 32 antigenic sites in intact and split rodent hepatocyte gap junctions. J Cell Biol 107:1817-1824.

Hahn AF, Brown WF, Konpman WI, Feashy TF (1990) X-I inked dominant hereditary motor and sensory neuropathy. Brain 113:15111525. 
Hudson L (1990) Molecular biology of myelin proteins in the central and peripheral nervous systems. Semin Neurosci 2:487-496.

Ionasescu VV, Trofatter J, Haines JL, Summers AM, Ionasescu R, Searby C (1992) X-Linked recessive Charcot-Marie-Tooth neuropathyclinical and genetic study. Muscle Nerve 15:368-373.

Jacobson S (1963) Sequence of myelination in the brain of the albino rat. J Comp Neurol 121:5-29.

Kanfer J, Parenty M, Goujct-Zalc C, Munge M, Bernier L, Campagnoni $\Lambda T$, Dautigny $\Lambda$, Zalc B (1989) Developmental expression of myelin proteolipid protein, myelin basic protein, and $2^{\prime}, 3^{\prime}$-cyclic nucleotide $3^{\prime}$ phosphodiesterase transcripts in different rat brain regions. $\mathbf{J} \mathrm{Mol}$ Neurosci 1:39-46.

Koeppen AH, Barron KD, Csiza CK, Greenfield EA (1988) Comparative immunohistochemistry of Pelizaeus-Merzbacher disease, the jimpy mouse, and the myelin-deficient rat. J Neurol Sci 84:315-327.

Konishi T (1990) Dye coupling between mouse Schwann cells. Brain Res 508:85-92.

Kumar NM, Gilula N (1992) Molecular biology and genetics of gap junction channels. Semin Cell Biol 3:3-16.

Kumar NM, Gilula NB (1986) Cloning and characterization of human and rat liver cDNAs coding for a gap junction protein. J Cell Biol 103:767-776.

Kumar S, Gordon MN, Espinosa de los Monteros MA, de Vellis J (1988) Developmental expression of neural cell type-specific mRNA in the myelin-deficient mutant rat brain: inhibition of oligodendrocyte differentiation. J Neurosci Res 21:268-274.

Kumar S, Macklin WB, Gordon MN, Espinosa del los Monteros A, Cole R, Scully SA, de Vellis J (1990) Transcriptional regulation studies of myelin-associated genes in myelin-deficient mutant rats. Dev Neurosci 12:316-325.

Kuraoka A, Iida H, Hatae T, Shibata Y, Itoh M, Kurita T (1993) Localization of gap junction proteins, connexin-32 and connexin-26, in rat and guinea pig liver as revealed by quick-freeze, deep-etch immunoelectron microscopy. J Histochem Cytochem 41:9/1-980.

Lemke G (1992) Myelin and myelination. In: Molecular neurobiology (Hall ZW, ed), pp 281-312. Sunderland, MA: Sinauer.

Lemke $G$ (1993) The molecular genetics of myelination-an update. Glia 7:263-271.

Lemke $G$, Axel R (1985) Isolation and sequence of a cDNA encoding the major structural protein of peripheral myelin. Cell 40:501-508.

Lemke G, Chao M (1988) Axons regulate Schwann cell expression of the major myelin and NGF receptor genes. Development 102:499504.

Linnington C, Webb M, Woodhams PL (1984) A novel myelin-associated glycoprotein defined by a mouse monoclonal antibody. J Neuroimmunol 6:387-396.

Macklin WB, Gardinier MV, Obeso ZO, King KD, Wight PA (1991) Mutations in the myelin proteolipid protein gene alter oligodendrocyte gene expression in jimpy and jimpy msd mice. $J$ Neurochem 56 : 163-171.

Majack RA, Larsen WJ (1980) The bicellular and reflexive membrane junctions of renomedullary interstitial cells: functional implications of reflexive gap junctions. Am J Anat 157:181-189.

Massa PT, Mugnaini E (1982) Cell junctions and intramembrane particles of astrocytes and oligodendrocytes: a freeze-fracture study. Neuroscience 7:523-538.

Meda P, Pepper MS, Traub O, Willecke K, Gros D, Beyer E, Nicholson B, Paul D, Orci L (1993) Differential expression of gap junction connexins in endocrine and exocrine glands. Endocrinology 133: 2371-2378.

Micevych PE, Abelson L (1991) Distribution of mRNAs coding for liver and heart gap junction proteins in the rat central nervous system. J Comp Neurol 305:96-118.

Mirsky R, Jessen KR (1990) Schwann cell development and the regulation of myelination. Semin Neurosci 2:423-435.

Morgan L, Jessen KR, Mirsky R (1991) The effects of cAMP on differentiation of cultured Schwann cells: progression from an early phenotype $(04+)$ to a myelin phenotype (Po+, GFAP-, N-CAM-, NGFreceptor-) depends on growth inhibition. $J$ Cell Biol 112:457-467.

Morgan L, Jessen KR, Mirsky R (1994) Negative regulation of the Po gene in Schwann cells: suppression of Po mRNA and protein in cultured Schwann cells by FGF2 and TGF $\beta 1, T G F \beta 2$ and TGF 33 . Development 120:1399-1409.

Naus CG, Celliveau DJ, Bechberger JF (1990) Regional differences in connexin 32 and connexin43 messenger RNAs in rat brain. Neurosci Lett 111:297-302.

Nicholson B, Dermietzel R, Teplow D, Traub O, Willecke K, Revel J-P (1987) Two homologous protein components of hepatic gap junctions. Nature 329:732-734.

Nishi M, Kumar NM, Gilula NB (1991) Developmental regulation of gap junction gene expression during mouse embryonic development. Dev Biol 146:117-130.

Norton WT, Poduslo SE (1973) Myelination in rat brain. Method of myelin isolation. J Neurochem 21:749-758.

Paul DL (1986) Molecular cloning of cDNA for rat liver gap junction protein. J Cell Biol 103:123-134.

Pedraza L, Owens GC, Green LAD, Salzer JL (1990) The myelinassociated glycoproteins: membrane disposition, evidence of a novel disulfide linkage between immunoglobulin-like domains, and posttranslational palmitylation. J Cell Biol 111:2651-2661.

Peters A, Palay SL, Webster HD (1991) The fine structure of the nervous system. New York: Oxford UP.

Phillips LH, Kelly TE, Schnatterly P, Parker D (1985) Hereditary motor-sensory neuropathy (HMSN): possible X-linked dominant inheritance. Neurology 35:-502.

Porter S, Clark MB, Glaser L, Bunge RP (1986) Schwann cells stimulated to proliferate in the absence of neurons retain full functional capability. J Neurosci 6:3070-3078.

Rabadan-Diehl C, Dahl G, Werner R (1994) A connexin-32 mutation associated with Charcot-Marie-Tooth disease does not affect channel formation in oocytes. FEBS Lett 351:90-94.

Radeke MJ, Misko TP, Hsu C, Herzenberg LA, Shooter EM (1987) Gene transfer and molecular cloning of the rat nerve growth factor receptor. Nature 325:593-597.

Reale E, Luciano L, Spitnas M (1975) Freeze-fracture faces of the perineurial sheath of the rabbit sciatic nerve. J Neurocytol 4:261270.

Robinson SR, Hampson ECGM, Munro MN, Vaney DI (1993) Unidirectional coupling of gap junctions between neuroglia. Science 262: 1072-1074.

Roth HJ, Hunkeler MJ, Campagnoni AT (1985) Expression of myelin basic protein genes in several dysmyelinating mouse mutants during early postnatal brain development. J Neurochem 45:572-580.

Rozear MP, Pericak-Vance MA, Fischbeck K, Stajich JM, Gaskell PC Jr, Krendel DA, Graham DG, Dawson DV, Roses AD (1987) Hereditary motor and sensory neuropathy, X-linked: a half century follow-up. Neurology 37:1460-1465.

Sambrook J, Fritsch EF, Maniatis T (1989) Molecular cloning. Cold Spring Harbor, NY: Cold Spring Harbor Laboratory

Sandri C, Van Buren JM, Akert K (1982) Membrane morphology of the vertebrate nervous system. Prog Brain Res 46:201-265.

Scherer SS, Asbury AK (1993) Inherited axonal ncuropathics. In: The molecular and genetic basis of neurological disease (Rosenberg RN, Prusiner SB, DiMauro S, Barchi RL, Kunkle LM, eds), pp 899-921. Butterworth-Heinemann.

Scherer SS, Braun PE, Grinspan JG, Collarini E, Wang D-y, Kamholz J (1994) Differential regulation of the $2^{\prime}, 3^{\prime}$-cyclic nucleotide $3^{\prime}$ phosphodiesterase gene in oligodendrocyte development. Neuron 12 : 1363-1375.

Scherer SS, Xu Y-T, Roling D, Wrabetz L, Feltri ML, Kamholz J (1994) Expression of growth-associated protein- $43 \mathrm{kD}$ in Schwann cells is regulated by axon-Schwann cell interactions and cAMP. J Neurosci Res 38:575-589.

Schiavinato A, Morandin AR, Guidolin D, Lini E, Nunzi MG, Fiori MG (1991) Perineurium of sciatic nerve in normal and diabetic rodents-freeze-fracture study of intercellular junctional complexes. J Neurocytol 20:459-470.

Schwab ME, Schnell L (1989) Region-specific appearance of myelin constituents in the developing rat spinal cord. J Neurocytol 18:161164.

Seamon KB, Padgett W, Daly JW (1981) Forskolin: unique diterpene activator of adenylate cyclase in membranes and in intact cells. Proc Natl Acad Sci USA 78:3363-3367.

Snipes GJ, Suter U (1995) Glial cell lineage and development. Annu Rev Neurosci 18:45-75.

Snipes GJ, Suter U, Welcher AA, Shooter EM (1992) Characterization of a novel peripheral nervous system myelin protein (PMP-22/SR13). J Cell Biol 117:225-238.

Sobue G, Pleasure D (1984) Schwann cell galactocerebroside induced 
by derivatives of adenosine $3^{\prime}, 5^{\prime}$-monophosphate. Science $224: 72$ 74.

Spray DC, Dermietzel R (1995) X-linked dominant Charcot-MarieTooth disease and other potential gap-junction diseases of the nervous system. Trends Neurosci 18:256-262.

Stahl N, Harry J, Popko B (1990) Quantitative analysis of myelin protein gene expression during development in the rat sciatic nerve. Mol Brain Res 8:209-212.

Sternberger NH, Quarles RH, Itoyana Y, Webster HD (1979) Myelinassociated glycoprotein demonstrated immunocytochemically in myelin and myelin-forming cells of developing rat. Proc Natl Acad Sci USA 76:1510-1514.

Stoll G, Trapp BD, Griffin JW (1989) Macrophage function during Wallerian degeneration of rat optic nerve: clearance of degenerating myelin and Ia expression. J Neurosci 9:2327-2335.

Suter U, Welcher AA, Snipes GJ (1993) Progress in the molecular understanding of hereditary peripheral neuropathies reveals new insights into the biology of the peripheral nervous system. Trends Neurosci $16: 50-56$.

Tetzlaff W (1982) Tight junction contact events and temporary gap junctions in the sciatic nerve fibres of the chicken during Wallerian degeneration and subsequent regeneration. J Neurocytol 11:839-358.

Thomas PK, Ochoa J (1984) Microscopic anatomy of peripheral nerve fibers. In: Peripheral neuropathy (Dyck. PJ, Thomas PK, Lambert EH, Bunge R, eds), pp 39-96. Philadelphia: Saunders.
Trapp BD, Quarles RH (1982) Presence of the myelin-associated glycoprotein correlates with alterations in the periodicity of peripheral myelin. J Cell Biol 92:877-882.

Trapp BD, Quarles RH (1984) Immunocytochemical localization of the myelin-associated glycoprotein. Fact or artefact? J Neuroimmunol 6:231-249.

Trapp BD, Quarles RH, Griffin JW (1984) Myelin-associated glycoprotein and myelinating Schwann cell-axon interaction in chronic $\beta, \beta$ '-iminodiproprionitrile neuropathy. J Cell Biol 98:1272-1278.

Trapp BD, Itoyoma Y, Sternberger NH, Quarles RH, Webster HD (1981) Immunohistochemical localization of P0 protein in Golgi complex membranes and myelin of developing rat Schwann cells. J Cell Biol 90:1-6.

Trapp BD, Andrews SB, Wong A, O'Connell M, Griffin JW (1989) Co-localization of the myelin-associated glycoprotein and the microfilament components, F-actin and spectrin, in Schwann cells of myelinated nerve fibers. J Neurocytol 18:47-60.

Webster HD, Favilla JT (1984) Development of peripheral nerve fibers. In: Peripheral neuropathy (Dyck PJ, Thomas PK, Lambert EH, Bunge R, eds), pp 329-359. Philadelphia: Saunders.

Yamamoto T, Hertzberg EL, Nagy JI (1991) Subsurface cisterns in $\alpha-$ motoneurons of the rat and cat: immunohistochemical detection with antibodies against connexin32. Synapse 8:119-136.

Zhang J-T, Nicholson BJ (1994) The topological structure of connexin 26 and its distribution compared to connexin 32 in hepatic gap junctions. J Membr Biol 139:15-29. 